\title{
Drought and Heat Stress in Cool-Season Food Legumes in Sub-Tropical Regions: Consequences, Adaptation, and Mitigation Strategies
}

\author{
Venugopalan Visha Kumari ${ }^{1}{ }^{\mathbb{D}}$, Anirban Roy ${ }^{1}$, Roshni Vijayan ${ }^{2} \mathbb{D}$, Purabi Banerjee ${ }^{1}$, Vivek Chandra Verma ${ }^{3}$, \\ Arpita Nalia ${ }^{1}$, Madhusri Pramanik ${ }^{1}$, Bishal Mukherjee ${ }^{1}$, Ananya Ghosh ${ }^{1}$, Md. Hasim Reja ${ }^{1}$, \\ Malamal Alickal Sarath Chandran ${ }^{1}$ (D), Rajib Nath ${ }^{1}$, Milan Skalicky ${ }^{4}$ (D), Marian Brestic ${ }^{4,5, *(D)}$ \\ and Akbar Hossain 6,*(D)
}

1 Department of Agronomy, Faculty of Agriculture, Bidhan Chandra Krishi Viswavidyalaya, Mohanpur 741252, India; visha.venugopal@gmail.com (V.V.K.); anirbanneelroy@gmail.com (A.R.); itsmepurabi1@gmail.com (P.B.); arpita.nalia6@gmail.com (A.N.); madhusri.bckv@gmail.com (M.P.); bishalmukherjee@gmail.com (B.M.); ananya.ghosh0193@gmail.com (A.G.); rejahasim92@gmail.com (M.H.R.); sarathagri@gmail.com (M.A.S.C.); rajibbckv@yahoo.com (R.N.)

2 AINP (Arid Legumes), Division of Pulses, Regional Agricultural Research Station-Central Zone, Kerala Agricultural University, Pattambi, Melepattambi P.O., Palakkad Kerala 679306, India; roshnivij@gmail.com

3 Defence Institute of High Altitude Research, Chandigarh 160002, India; vivekverma95@gmail.com

4 Department of Botany and Plant Physiology, Faculty of Agrobiology, Food, and Natural Resources, Czech University of Life Sciences Prague, Kamycka 129, 16500 Prague, Czech Republic; skalicky@af.czu.cz

5 Department of Plant Physiology, Slovak University of Agriculture, Nitra, Tr. A. Hlinku 2, 94901 Nitra, Slovakia

check for

updates

Citation: Kumari, V.V.; Roy, A.; Vijayan, R.; Banerjee, P.; Verma, V.C.; Nalia, A.; Pramanik, M.; Mukherjee, B.; Ghosh, A.; Reja, M.H.; et al. Drought and Heat Stress in Cool-Season Food Legumes in Sub-Tropical Regions: Consequences, Adaptation, and Mitigation Strategies. Plants 2021, 10, 1038. https:// doi.org/10.3390/plants10061038

\section{Received: 24 April 2021}

Accepted: 18 May 2021

Published: 21 May 2021

Publisher's Note: MDPI stays neutral with regard to jurisdictional claims in published maps and institutional affiliations.

Copyright: (c) 2021 by the authors. Licensee MDPI, Basel, Switzerland. This article is an open access article distributed under the terms and conditions of the Creative Commons Attribution (CC BY) license (https:// creativecommons.org/licenses/by/ $4.0 /)$.
6 Department of Agronomy, Bangladesh Wheat and Maize Research Institute, Dinajpur 5200, Bangladesh

* Correspondence: marian.brestic@uniag.sk (M.B.); akbarhossainwrc@gmail.com (A.H.)

Abstract: Drought and heat stress are two major abiotic stresses that challenge the sustainability of agriculture to a larger extend. The changing and unpredictable climate further aggravates the efforts made by researchers as well as farmers. The stresses during the terminal stage of cool-season food legumes may affect numerous physiological and biochemical reactions that may result in poor yield. The plants possess a good number of adaptative and avoiding mechanisms to sustain the adverse situation. The various agronomic and breeding approaches may help in stress-induced alteration. The physiological and biochemical response of crops to any adverse situation is very important to understand to develop mechanisms and approaches for tolerance in plants. Agronomic approaches like altering the planting time, seed priming, foliar application of various macro and micro nutrients, and the application of rhizobacteria may help in mitigating the adverse effect of heat and drought stress to some extent. Breeding approaches like trait-based selection, inheritance studies of marker-based selection, genetic approaches using the transcriptome and metabolome may further pave the way to select and develop crops with better heat and drought stress adaptation and mitigation.

Keywords: heat stress; drought stress; legumes; adaptation; mitigation strategies

\section{Introduction}

Food legumes or cool-season legumes are protein-rich and are commonly called 'poor man's meat'. They help to meet the diverse demand for food, fiber, and fodder in several agricultural systems [1,2]. They are known for their completeness in a balanced diet and also form an integral part of the vegetarian diet. Pulses like broad beans (Vicia faba), lupin (Lupinus spp.), lentils (Lens culinaris), chickpeas (Cicer arietinum), grass peas (Lathyrus sativus), dry peas (Pisum sativum), and the common vetch (Vicia sativa) are included in the list of cool-season pulses [3]. They are named so mainly because of the cooler conditions they 
require for vegetative growth. Though cool-season food legumes are of less importance in world production and consumption, they form a very imperative component in the Indian diet.

Food supply, as well as nutritional security, has been highly challenged by rising temperatures. Small farmers are severely impacted by heat stress affecting their crops [4]. More so than global temperature rise, local temperature increases are of much concern as they can drastically affect crop production. The prevalence of high temperatures is anticipated to amplify in the near future [5]. More flowers per plant enhance yields per plant and ultimately better production. However, various stress cause an imbalance in the production of the reproductive organ affecting the yield. Under various abiotic stresses, among which heat and drought are a major threat nowadays, hamper the reproductive ability of crops. Plant stress can be broadly grouped into biotic stress and abiotic stress. The stress caused by any living organisms such as pathogenic bacteria, fungus, viruses, nematodes, insects, and phenerogamic plants are known as biotic stresses, and stress caused by the physical environment like temperature, moisture, relative humidity, sunshine, etc., are known as abiotic stresses. Drought and heat are the major abiotic stresses that have been reported to reduce crop productivity and yields and affect food security. Considering the current change in climate, we expect an increase in the severity of abiotic stresses, which may impact global food security.

The escalating variability in crops is expected to result in plants more sensitive to heat and drought stress [6]. Changes in temperature thresholds, even by a single degree beyond the threshold level, are sure to affect the production potential of crops [7]. Heat stress can cause physiological, morphological, anatomical, and biochemical changes in the growth and development of a plant that may finally affect the yield of the crop $[7,8]$. Though the stresses have a negative effect from the germination to the reproductive stage, the latter is considered more serious as it affects productivity to a larger extent, and even stress at the reproductive stage invites root diseases [9].

Plants are known for their genetic potential in allowing them to adapt to an unfavorable environment. However, it varies depending on the crop, variety, and the management option they are exposed to and also the quantum of exploitable genetic variation present in its germplasm [10]. As mentioned earlier, even a slight variation from the normal condition may affect yields; it is very important to understand the stress complex and act accordingly. This review presents a zest of the effect of heat and drought stress, its effect on plants, and mitigation strategies.

\section{Drought and Heat Stress in Cool-Season Food Legumes}

Drought stress takes place if the air temperature is high and soil and atmospheric humidity are low; disproportionate water uptake and evapotranspiration from the soil results in this condition [11]. Plant growth through cell division, enlargement, and differentiation is impaired along with mitosis and cell elongation [12]. The stress hinders cell enlargement owing to loss of turgidity. The loss of turgidity results in smaller and lesser leaves, thus reducing the photosynthetic area [13]. The effect of drought stress is generally impulsive as various factors, including rainfall patterns, water holding capacity of the soil, and evapotranspiration may influence it. Drought stress also affects growth; photosynthesis assimilates partitioning and hampers yields [14,15].

When soil and or air temperature increase beyond a threshold level for a stipulated time is known as heat stress, which may affect crop growth. It may result in various visual symptoms like sun scorching, leaf burn, leaf discoloration, and senescence [16,17]. The duration of which the crop is at a high-temperature matters a lot under heat stress. Reproductive growth is largely affected under high temperatures. A temperature $\geq 30{ }^{\circ} \mathrm{C}$, can result in poor pollen viability, pollen shedding, poor pollen germination and growth, and decreased pollen elongation [18].

Though both stresses have differences in their occurrence, most of the time, they are observed together, causing a lot more negative effects on plant growth and yield than 
what they cause alone. For this very reason, both the stress needs to be considered [19]. Severe yield losses have been reported by researchers in many crops. Some cool-season food legumes affected by drought and heat stress are given in Table 1.

Table 1. Yield losses caused by drought and heat stress in some major food legumes.

\begin{tabular}{cccc}
\hline Legumes & Stress & Yield Losses (\%) & References \\
\hline Chickpea & Heat and drought & $40-45$ & {$[20]$} \\
Lentil & Heat and drought & 57 & {$[21]$} \\
Soybean & Drought & $73-82$ & {$[22]$} \\
Cowpea & Drought & 29 & {$[23]$} \\
Faba bean & Drought & 40 & {$[24]$} \\
Field pea & Drought & $21-54$ & {$[25]$} \\
\hline
\end{tabular}

\section{Change in Climate: A Major Reason for Heat and Drought Stress in Cool-Season Food Legumes}

The high pace increase in the global population and drastically changing climate is challenging global food security to a large extent [26]. The sustainability of an agricultural system is at high risk due to climate change. The reduction in annual rainfall, along with the erratic pattern of monsoon rains, possesses a high threat of frequent drought around the world [27]. Though a surge in temperature is reported positive in some cooler parts and crops, the larger impact is depressing [28]. India being an agricultural nation, the vulnerability of the changing climate is of larger magnitude than in other nations. It is very clear that among all the stresses, drought and heat stress are the major ones for agricultural production [29]. Both these stresses have a larger impact in reducing the yield and causing a negative impact on farmer livelihoods than others.

Food legumes can acclimatize to a wide range of soil and climatic conditions, and hence, could be a component in adaptation strategies to the changing climate. As these coolseason food legumes (CSFLs) are grown in the Rabi season, the major hurdle a farmer faces is for its timely sowing. Change in weather is forcing farmers to begin to grow their crops late (late Kharif) as there is a shift of monsoon rains from June-July to August-September. Apart from this, the growers prefer long-season Kharif crops. These long-season crops often keep the land occupied till the end of November, delaying the sowing of the subsequent CSFLs. The sowing may be further delayed due to excessive drought due to untimely and unpredicted rains [30].

\subsection{Consequences of Heat and Drought Stress on Food Legumes}

Cool-season food legumes (CSFL) are more susceptible to temperature variation than warm-season food legumes. Increasing the threshold level always results in the growth and productivity of legumes [31]. In most cases, even an increase of one degree in temperature will matter a lot and is considered as heat stress in these plants [32], which has serious implications for growth and biochemical function [7].

Though any small increase in temperature is considered a stress, the impact largely depends on the level and duration of the exposure. Larger impacts have been observed in the physiological processes of crops, such as photosynthetic reserves, nitrogen assimilation [33], protein catabolism, and the accumulation of the end products of lipid peroxidation $[34,35]$. It also affects the phenology of crops, including effects on photosynthetic machinery, which are affected due to non-robust photosystems; in most cases, the duration gets shortened, resulting in poor yields [36]. Stress affecting CSFLs during their reproductive stage has been reported in legumes such as chickpea [37,38], field peas [39], and others.

The critical temperature for heat tolerance in chickpeas has been reported as being much higher than the tolerances of other legume crops like faba beans, field peas, and lentils [40]. A temperature increase beyond $30^{\circ} \mathrm{C}$ causes stress in chickpeas. It may lead to an early start to the reproductive stage, affects the physiology of flowers, and may result in a lower seed set [41]. Similar results have been reported by GrossandKigel [42] in beans. In the common bean, as reported by Nakano et al. [43], a change in night and day temperature of 
$27 / 32{ }^{\circ} \mathrm{C}$ during sporogenesis may result in reduced pollen viability, pollen sterility, and low pod numbers and seed sets. Maheshwari et al. [44] reported on the detrimental effect of high temperature on photosynthesis, respiration process, cell water relations, and membrane permanence, compatible solute adjustment, and the accumulation of antioxidant compounds, etc. Threshold temperature for several cool-season food legumes are listed in Table 2.

High-temperature stress causes oxidative damage by the formation of ROS (reactive oxygen species) in plants [45]. ROS affect cell functioning by damaging membranes, lipids, and proteins. Oxidative damage further leads to membrane instability. A higher lipid and protein peroxidation was reported under drought stress conditions compared with normal conditions in field peas [46]. Membrane stability further affects chloroplasts and thus photosynthesis and assimilate transportation. The outcome is largely a reduction in yields and quality.

Stomatal closure is the first and foremost response to any stress to avoid water loss. This may be a response to lower leaf water potential [47] or lower atmospheric humidity [48]. Further closing results in $\mathrm{CO}_{2}$ intake, which leads to oxidative damage and no assimilation. Almost all the important and essential nutrients are taken up by the roots along with water. Prevailing stresses reduce the movement of nutrition and water and retards growth. The other interesting fact reported under drought conditions is the response of stomata to ABA [49]. However, the intensity of response to ABA may be different between plant species [50].

Table 2. Threshold temperature for cool-season food legumes.

\begin{tabular}{ccc}
\hline Legumes & Temperature & Reference \\
\hline Chickpea & $15-30$ & {$[51]$} \\
Faba bean & 25 & {$[52]$} \\
Lentil & $15-33$ & {$[53]$} \\
Lupins & $20-30$ & {$[54]$} \\
Field pea & $20-34.3$ & {$[55]$} \\
\hline
\end{tabular}

\subsection{Impact on Seed Setting and Yield}

Researchers and farmers are concerned about seed setting and yield, a stage of growth that deals with transport of source from leaves to reproductive organs, and deals with processes related to the storage of nutrients [56]. High-temperature stress in legumes results in larger yield losses, mainly because of poor seed setting [57-59]. The impact of high temperature on seed setting of cool-season food legumes is given in Table 3. Seed filling time is shortened due to high temperatures, resulting in a reduction in crop duration and yield [60]. The reduction in seed filling time may reduce seed weight [61]. The crop experiencing stress due to higher temperatures $\left(30-35^{\circ} \mathrm{C}\right)$ during the reproductive phase can result in a reduction of legume yield [59,62].

Table 3. Impact of high temperature on seed setting of cool-season food legumes.

\begin{tabular}{|c|c|c|c|}
\hline Legumes & Temperature $\left({ }^{\circ} \mathrm{C}\right)$ & Impact on Seed Setting & Reference \\
\hline Chickpea & $34 / 19$ & $\begin{array}{l}\text { Epidermis wall thickening of } \\
\text { anthers, ovule abnormality, } \\
\text { pollen germination, and } \\
\text { receptivity }\end{array}$ & [40] \\
\hline Lentil & $32 / 20$ & $\begin{array}{l}\text { Pod abortion reduced flower no. } \\
\text { shortened flowering period, } \\
\text { pollen germination, pollen tube } \\
\text { length, pod length }\end{array}$ & {$[63,64]$} \\
\hline Lupins & $33 / 28$ & Ovule abortion & [65] \\
\hline Field pea & $27 / 36$ & $\begin{array}{l}\text { Pollen germination, tube length, } \\
\text { and pod growth }\end{array}$ & [66] \\
\hline
\end{tabular}




\section{Mitigation Strategies}

\subsection{Agronomic Strategies}

\subsubsection{Application of Plant Nutrients as a Foliar Spray}

Under heat stress, high water status can be attained by various macronutrients and micronutrients. The macronutrients and micronutrients like potassium, calcium, boron, selenium, and manganese activate various physiological and stomatal functions in plants [67]. Apart from the stress amelioration, foliar spray of micronutrients can also improve the nutritional quality of crops [68].

Zinc is another micronutrient known for its metabolic and regulatory functions [69], which also plays a pivotal role in the reproductive phase of the crop. Zinc deficiency in the soil affects the development of anthers [70], pollen viability [71], and inhibits pollen-stigma interaction [72]. Another micronutrient, Iron (Fe), is important for various biochemical pathways in plants $[73,74]$. The impact of boron deficiency on assimilate partitioning may greatly influence the ability of plants to cope with other unfavorable environmental conditions such as soil water deficits and low supplies of other nutrients. Boron plays an important role in the reproductive growth of plants $[75,76]$. The role of boron for pistil development and pollination to fertilization has also been reported by many researchers. In oilseed rape, $\mathrm{Xu}$ et al. [77] observed the arrested development of ovules and embryo sacs in flowers from low B plants. They also noted unusual development of stigmatic papillae. Another study has recorded almost double the yield with the foliar spray of $\mathrm{B}+\mathrm{Fe}$ at $0.5 \%$ than the treatment with no foliar spraying in lentils, which were sown late and experienced both heat and drought stress [78].

\subsubsection{Plant Growth Regulators}

Plant growth regulators are also known for their effects in mitigating stress. They help in regulating hormone transduction pathways [79]. The role of auxins during heat stress responses has recently attracted attention, and there is some strong experimental evidence regarding their role in thermo-protection. Auxins have been implicated in imparting thermo-tolerance to reproductive components (anthers) [80]. Salicylic acid, cytokinin $\mathrm{GA}$, and ABA have been reported for their usefulness in mitigating the adverse effect of drought stress (Table 4) and temperature stress by increasing the water potential and sink capacity $[81,82]$.

Table 4. Protective effects of plant growth regulators in cool-season food legumes.

\begin{tabular}{|c|c|c|c|}
\hline Legumes & Protectants & Protective Effects & References \\
\hline Chickpea & $\mathrm{ABA}$ & $\begin{array}{l}\text { More growth, less oxidative damages decreased } \\
\text { MDA and } \mathrm{H}_{2} \mathrm{O}_{2} \text { contents. }\end{array}$ & [83] \\
\hline Wintergreen gram & Salicylic acid & $\begin{array}{l}\text { Its endogenous level in heat-stressed mungbean } \\
\text { plants enhances antioxidant enzyme activities to } \\
\text { impart thermotolerance. }\end{array}$ & [84] \\
\hline Chickpea & $\begin{array}{l}\text { Salicylic acid and } \\
\text { Putrescine }\end{array}$ & $\begin{array}{l}\text { Increased leaf proline content, greater lipid } \\
\text { peroxidation, and accelerated antioxidant enzymes } \\
\text { (CAT, APOX, POD, and SOD) activity. }\end{array}$ & [85] \\
\hline Faba bean & $\begin{array}{l}\text { Exogenious Gibberelic } \\
\text { acid }\end{array}$ & $\begin{array}{c}\text { Balanced activity of osmoprotectants, nutrients, } \\
\text { antioxidant defense mechanism, and } \\
\text { phytohormones. }\end{array}$ & [86] \\
\hline Lentil & $\begin{array}{c}\text { Exogenious proline and } \\
\text { Betain }\end{array}$ & $\begin{array}{l}\text { Upregulation of homeostasis in lentils under stress } \\
\text { conditions, modulation of glutathione S-transferase, } \\
\text { glyoxalase I, and GSH content with a decrease in } \\
\text { GSSG and } \mathrm{H}_{2} \mathrm{O}_{2} \text { levels, thereby reducing the toxic } \\
\text { impacts of reactive oxygen species and the } \\
\text { methylglyoxal detoxification system. }\end{array}$ & [87] \\
\hline Field pea & $\begin{array}{c}\text { 24-Epibrassinolide and } \\
\text { Thiourea }\end{array}$ & $\begin{array}{c}\text { Enhanced contents of relative leaf water, total } \\
\text { chlorophyll, and soluble sugars in response to } \\
\text { drought stress. }\end{array}$ & [88] \\
\hline
\end{tabular}




\subsubsection{Seed Priming}

Seed priming is an improved agronomic intervention involving restricted hydration of seeds before sowing [89] to influence the performance of a crop on a long-term basis [89,90]. Priming develops tolerance to stress during the seedling stage [91] as well as throughout the growing season of a crop [92]. Priming induced faster germination and uniform emergence [93-99], allowing farmers to cope with the time lost in drought [100]. Compared to the unprimed seeds, generally, primed ones give rise to more robust seedlings with extensive root systems and complete their life cycle earlier. Many researchers have established the fact that seed priming is a great technique for accelerating crop growth and flowering for better yields in rice fallows [101,102]. In a way, these properties promote a healthier stand establishment of a crop by expanding the area for soil water and nutrient uptake. On the other hand, seed priming also promotes leaf area enlargement for capturing more solar radiation, thereby accelerating photosynthetic activity and consequent increment in yield potentials of crops [103]. All these advantages may prove seed priming to be an outstanding approach to escape terminal heat and drought stress [104-106]. In fact, priming is a very affordable practice to alleviate the adversities of abiotic stress in crop plants [107-111], before or after the germination of seed and stand establishment [112-115]. The reason behind the better preparedness of primed seeds for possible stresses may be the activation of the response of antioxidant systems through priming, and $\mathrm{Se}$ and $\mathrm{Si}$ application protects against drought stress if applied during priming [89].

Priming of seeds with $\mathrm{KH}_{2} \mathrm{PO}_{4}, \mathrm{Na}_{2} \mathrm{HPO}_{4}$, etc., or water have been found to develop drought withstanding ability in crops [116]. BABA ( $\beta$-amino butyric acid), a non-protein amino acid, has been reported to impart resistance against abiotic stress in plants [117-120]. This may be a result of hormonal activity such as salicylic acid, abscisic acid, and ethylene $[119,121]$. The literature also contains reports regarding priming seeds with bacterial inoculum, which stimulated the enzymatic activity in stress-induced plants with respect to ROS scavenging property [122-125].

\subsubsection{Planting Method}

Winter pulses are more susceptible to drought, especially during the later part of the growth stages, if not supplemented with lifesaving irrigation or grown under drought conditions with residual soil water. Relay sowing of cool-season legume crops after rice reduces the negative impact of terminal drought and heat stress during the reproductive phase of the pulse crop by overlapping part of its early growth stage with the previous crop. It has been reported by Gangwar et al. [126] and Kar and Kumar [127] that legumes grown after wet season rice with reduced or minimum tillage give a higher yield. The relay sowing of lentils is done in some areas of eastern India by broadcasting the seed in the standing rice crop 15 days prior to its harvesting without any tillage, which grows well by utilizing the residual soil water present in the field $[127,128]$.

The major components of conservation agriculture, i.e., reduced tillage practices and surface retention of crop residues, imparts significant direct and indirect effects on drought conservation, reduction in soil temperature, and runoff losses. It may help in balancing soil hydrothermal properties. Conservation tillage practices, along with mulching, have a very positive impact on the growth and productivity of pulses (chickpeas). Soil with hardpans needs deep tillage to conserve soil moisture. Layek et al. [128] and Ghosh et al. [129] reported that adopting suitable planting techniques (relay cropping), along with crop residue retention in rice fallows, helps mitigate terminal drought in lentils by reducing evaporation loss hence conserving soil moisture. In dryland areas, chickpea and field pea can be grown in FIRB (Furrow irrigated raised bed system) to conserve soil water as well as enhancing productivity [130]. To downturn, the adverse effect of drought and heat stress on coolseason legumes needs the choice of proper resource conservation practices, tillage methods, cropping systems, selection of appropriate pulse varieties (varietal diversification), etc. 


\subsubsection{Planting Time}

Time of sowing is the most important nonmonetary input that has significant effects on crop growth, phenological development, insect-pest, weed dynamics, and crop productivity. Sowing date is an important determinant of crop yields. Delayed sowing results in rising temperature and longer photoperiod, and consequently, rapid vegetative growth that hastens crop maturity. Terminal heat and drought stress restrict vegetative growth and branching, leading to forced maturity and lower yields [131]. A yield reduction of $20 \%-70 \%$ of yield reduction occurs in cool-season pulses like chickpeas, field peas, faba beans, and lentils due to flower drop and pod abortion caused by rising of temperature above $25^{\circ} \mathrm{C}$ [132]. Crop establishment, growth, development, and the environment during seed set are all influenced by the time of sowing [133]. Heat stress induces flowering before the plant has grown sufficiently to bear a good crop. Rabi greengram can be sown up to the end of December, and this is practiced in the southern part of India, where the winters are not severe [134].

In the case of late sown cool-season legumes, the increase in leaf temperature causes decreased leaf water potential and relative water content, which ultimately reduces the photosynthetic rate of the crop [14]. As the rate of transpiration and plant growth are highly related and affected by appropriate planting time, this will be one of the most vital agronomic practices to be adopted for getting higher yield, specifically under heatstressed situations [135]. In principle, delays in sowing beyond the optimum dates result in a progressive reduction in reproductive growth, i.e., flowering, pod formation, and ultimately, crop yield.

4.1.6. Role of Plant Growth-Promoting Rhizobacteria and Arbuscular Mycorrhizal Fungal Inoculation in Mitigating Stress

Plant growth-promoting rhizobacteria (PGPR) have a very important role in mitigating drought stress in legumes [136]. The mechanism by which it deals with drought stress includes mechanisms such as phosphorus solubilization, organic acids, nitrogen fixation, production of siderophores, and production of enzymes such as ACC deaminase $[137,138]$. The efficiency in water use efficiency through hormonal signaling has also been reported [139]. Phytohormones like gibberellins, auxins, cytokinins, ABA, and ethylene can also be synchronized by PGPR [140]. In a study in lentils, it was found that application of Pseudomonas putida enhanced nodulation and plant growth that resulted in better drought resistance [141]. Under drought stress situations, arbuscular mycorrhizal fungi (AMF) help in water and nutrient uptake [142]. They increase the levels of osmoprotectants and antioxidant potential thus, decreasing lipid peroxidation [143]. AMF plays a vital role in improving soil structure and soil water retention ability through the formation of soil aggregates [144].

\subsection{Genetics and Genomics Approaches}

\subsubsection{Genetics/Breeding Approaches}

Breeding strategies deployed for cool-season legume breeding are shown in Figure 1.

\section{Target Traits for Breeding Drought and Heat Tolerance}

Stress causes changes in plant physiology that cause reproductive malfunctioning. Stress sensing through signal transduction quickly hampers several metabolic changes, especially in reproductive organ development, loss of several dehydrogenase activities, sucrose metabolism, starch synthesis and partitioning, phytohormonal sensitivity, etc. For traits like early flowering, early vigor in lentils can be used as a drought escaping mechanism. Less cell membrane injury and early seedling growth, i.e., quick establishment, are key traits for drought tolerance in lentils [145]. Lesser shoot/root ratios can be used as selection criteria for drought tolerance. Vegetative to reproductive stages are vulnerable to stress irrespective of crops, including cereals, with effects varying over wider ranges [146]. Deep root, photosynthesis-related traits, and osmotic adjustments are major selection 
criteria that can be used for pigeon pea for drought tolerance screening [147]. A profuse rooting system, early maturity with reasonable yield during drought, are widely used traits for selection during drought stress for chickpeas [148].

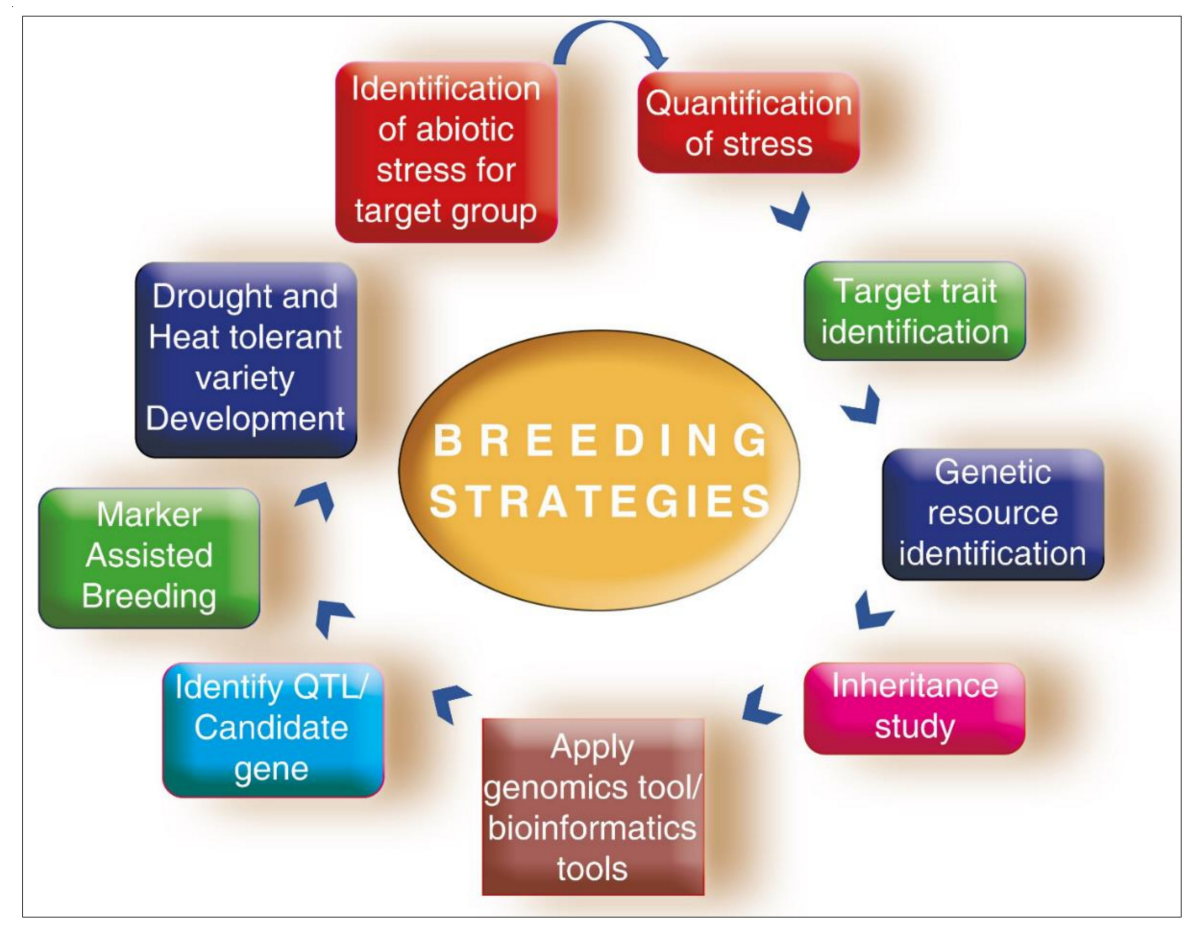

Figure 1. Breeding strategies deployed for cool-season legume breeding.

Inheritance Studies

Identification of genetic elements for drought tolerance can be exploited using largescale germplasm screening, including wild species and cultivated exotic and indigenous collections. A wide potentiality for drought tolerance ability has been exploited in wild lentils [149]. To increase the speed of breeding for drought tolerance through germplasm screening, variability can be created in chickpeas by inducing mutations [150]. Regarding genetics, inheritance studies for target traits are important, as conventional plant breeding strategies take a long time to develop a suitable genotype selection from segregating population; hence, marker-assisted technologies are needed to increase the speed of the election cycle and improve genetic gains. During the development of generation segregation, population mapping is key for identifying the affected genes and the nature of their effects, and their QTLs and target genes. Drought tolerance traits are governed by a complex set of polygenes, but in cowpeas, drought resistance is reported to be governed by a single dominant gene [151].

\section{Traits and Their Susceptibilities}

Changes in night temperature affect optimum biomass [152], random heat and drought cause drastic yield reductions [153]. Combined heat and drought stress cause hampered photosynthesis rates [154]. Unusually prolonged winter spells lead to shorter reproductive durations and less reproductive partitioning, including leaf physiology, which has the effect of lowering photosynthate production. Early heat stress causes untimely flowering and leads to drastic yield reductions; pre-flowering heat stress induces lower numbers of flowering buds, even basic cellular homeostasis and chlorophyll damage occurs due to unusual photooxidative damage due to PSI activation; breeding is targeted at inhibiting this activation process [155]. Post flowering heat stress causes flower drying. Moisture deficit stress at the early vegetative stage reduces branching and flowering in stunted seedlings; even moisture deficit stress at the reproductive stage causes forced maturity. Excessive 
drought at the early stage and reproductive stage causes early senescence and forced maturity. Even in the case of high-temperature rises during vegetative and reproductive stages drastically hampers the yield capacity of plants.

\subsubsection{Genomics Approaches}

Drought is the most complex target trait for breeding as, during drought stress, some other abiotic stress or biotic stress may be associated, making it more complex. Mechanisms of drought and its implication for breeding have been well studied in a few crops, and that information can be used using a genomic tool for other crops [156]. Under drought and heat stress, from perception to signal transduction to physiological adjustment towards plant tolerance by minimizing the detrimental effect on reproductive fecundity, which is controlled by a set of interacting loci under QTL, and understanding that quantitative loci through genomic approaches, is key [157]. Even whole-genome resequencing programs have helped to identify a large number of SNPs and copy number variants have been used in association studies in various crops. Sequence analysis using various bioinformatics applications for exploiting undeciphered features of gene-like structures studies can be performed for identifying the genetic causes of tolerance under changing environmental conditions [158].

\section{Mapping of Genomic Regions for Complex Traits}

As roots first sense drought, root traits like root-length density, root biomass, and root length have been used in chickpea breeding for terminal drought tolerance $[159,160]$. For drought tolerance QTL identification, a QTL-Hotspot has been identified in a RIL population generated for mapping of drought tolerance [161], covering a large set of main effects and epistatic QTLs.

\section{Candidate Gene Discovery}

The exploitation of available genetic potential has been utilized in the past as a common strategy [162]. Since long candidate gene identification followed by validation can help crop improvement [163], in silico analysis from available genomic information in the EST database can be used in crop breeding through identifying various EST-based marker development and genotyping [164]. Several high throughput NGS platforms for deciphering unexploited genomic information and also various third-generation genomic technologies have been used in breeding programs for understanding the genetics of target strategies $[165,166]$. Utilization of common genetic information for various crops is still under development as in several crops, where genomic information is not sufficiently strong that it can overcome syntenic crop information as Cicer, Lens, Vicia, and Medicago have $40 \%$ genomic similarity [167]. cDNA library generation for particular stress can yield strong genomic information regarding the transcript response to that stress [168].

Abiotic stress is a complex mechanism as it is controlled by a number of genetic factors and their interaction leads to tolerance. Trait-based mapping of the abiotic stress plays an important role in accelerating the speed and accuracy of breeding [10]. To find the entire story, major signaling genes are identified that actually perceive the stress and regulate metabolism, ultimately leading to considerable yields under stress. In this context, the candidate gene approach is linked to the genomics approach for genetic gain under stress conditions. Mammalian AMPK (AMP-activated protein kinase) and budding yeast SNF1 have a plant ortholog, the SNF1 (sucrosenon-fermenting1)-related protein kinases1 (SnRKs1). These are evolutionarily conserved kinases. In response to declining energy levels, these metabolic sensors are activated, i.e., when glucose and sucrose amount reduces during stress. As complex trimeric SnRK1, after sensing stress in the cell, ceases carbohydrate translocation to ensure expenditure of available energy to that particular area. When SNF1/AMPK/SnRK1 kinases are activated, they trigger reprogramming of transcriptional and metabolic activities and, in turn, restore energy homeostasis, which thereby develops tolerance to adverse conditions. This is achieved by general repression 
of anabolism and induction of catabolic processes. The SNF1/AMPK/SnRK1 kinases typically function as a heterotrimeric complex that is controlled by multiple mechanisms and requires phosphorylation of a conserved activation loop residue for activity. The complex is made up of $\beta$ and $\gamma$ regulatory subunits and an $\alpha$-catalytic subunit [169]. The SnRK1 heterotrimeric complex exists in several isomeric forms, acts as a metabolic regulator for nutrient deficiency in plants. By the characterization of the seeds of M. trancatula, isomeric forms of $\beta$ (MtAKIN $\beta 1-\beta 4$ ) and $\gamma$ (MtAKIN $\beta \gamma, \operatorname{MtSNF} 4 \beta$, MtAKIN $\gamma$ ) regulatory subunits were identified, which helped to gain insight into the development of responses to stress conditions in the plants. Transcripts accumulation was found to be different in vegetative as well as seed tissues and also modulated differently with the imposition of stress and during the germination process.

Transcription factors (TFs) play the major roles for downstream gene up and downregulation upon exposure to stress for short or long-term stress via interaction through cis-acting elements [170]. The role of the bZIP transcription factor has been studied in drought tolerance, and WRKY and NAC TFs have also been widely studied and exploited for their extensive role in cereals crops [171]. An important class of TFs, DREB (Dehydration responsive element binding)/CBF (C-repeat binding factors), which bind to DRE (Dehydration responsive element) functions, providing multiple stress tolerance, and growth-dependent MADS-box TFs manipulate flowering behavior [172].

It generally functions more in an ABA-independent manner through DRE/CRT (Crepeat) cis-acting elements and AP2/ERF (Apetala2/Ethylene Responsive Factor) DNA binding domain. So understanding the mechanism of heat stress dissecting the new area in lentils to make the crop more tolerant to heat has been unexplored until now, although an experiment using Medicago trancatula revealed upregulation of the MtCBF4 gene during drought, salinity, and cold stress [173]. As most abiotic stress tolerance mechanism overlaps, finding more in lentils is another input that could lead to genetic improvements. Several major candidate genes that have been exploited for drought tolerance, including the LEA protein group, which have been validated through a transgenic approach, which can be used for genetic polymorphism study of these genes in breeding programs in terms of sequence-based polymorphisms and expression [174]. Adaptation under elevated temperature is responded to by changing flowering gene expression, including series of FT genes, which enhances adaptation and response can be useful in candidate genebased breeding.

\section{Markers for Genetic Dissection}

A wide range of markers are used for searching for polymorphisms, mapping, and marker-assisted breeding, including RAPD and RFLP [175]. Genomic information in food legumes is not as strong as in other cereal crops. Syntenic information and cross-species transfer of SSR has been practiced, following strong genomic information that facilitated the development of crop-specific SSR markers [176]. A large number of SSR markers, including EST SSR, have been used for 'QTL Hotspot' identification in chickpeas [176]. Interaction of simple screening along with biochemicals protecting cells and marker development for QTLs have been the most comprehensive approach since the improvement of genomics technologies [177].

\subsection{The Transcriptome and Metabolome}

This strategy is now a common genomic approach for gathering initial information for any crop regarding any abiotic stress for orphan crops as well as well exploited crops in terms of genomic information. The related abundant transcripts which are responsive to stress can be identified through this technique covers a whole-genome picture for that particular trait. Even basic pathways that are linked with the stress response and tolerance can be identified, which provides a basic understanding for breeders of the traits involved and can inform breeding directions under such conditions. The drought tolerance gene has been dissected using spatiotemporal gene expression analysis using NGS in chickpeas [164]. 
Genes responsive to drought tolerance in lentils have been exploited through transcriptome analysis [177] for seedling drought tolerance. Complete metabolic profiling under control as well as stress condition gives an idea regarding metabolic changes and metabolic regulations under various stresses for various pathways that are major determining factors for yield components, i.e., complete development of the reproductive part of the crop. The complete metabolic picture is the initial clue regarding the candidate gene for target trait-based breeding.

The advancement of transgenic crop approaches, especially gene-based technology, appears to be the most valuable tool for resistance against heat and drought stresses. The basic mechanism of the transgenic crop approach for heat and drought stress is shown in Figure 2. The tools of biotechnology help us alter the genetic makeup of crops to protect them against devastating abiotic stress conditions. The identification of the specific genes which make the organisms resistant to abiotic stress and transfer them to crops from any organism, even from different species, can be achieved with the advances made in biotechnology [178]. The engineering of stress tolerance genes that encode antioxidants, compactable solutes, and growth regulators has been the major emphasis. For developing drought-tolerant crops, genetic engineering has been utilized for improving the gene expression of glycine betaine in higher plants, which encodes for two enzymes, choline monooxygenase and beta aldehyde dehydrogenase [179]. The genes regulated by the DREB and AREB proteins are also being studied for drought stress tolerance in several crops [180]. Overexpression, as well as underexpression, of certain genes in transgenic plants, have been studied for drought tolerance. Kudo et al. [181] reported that the overexpression of $D R E B 1 A$ and OsPIL1 genes improved drought tolerance in transgenic plants.

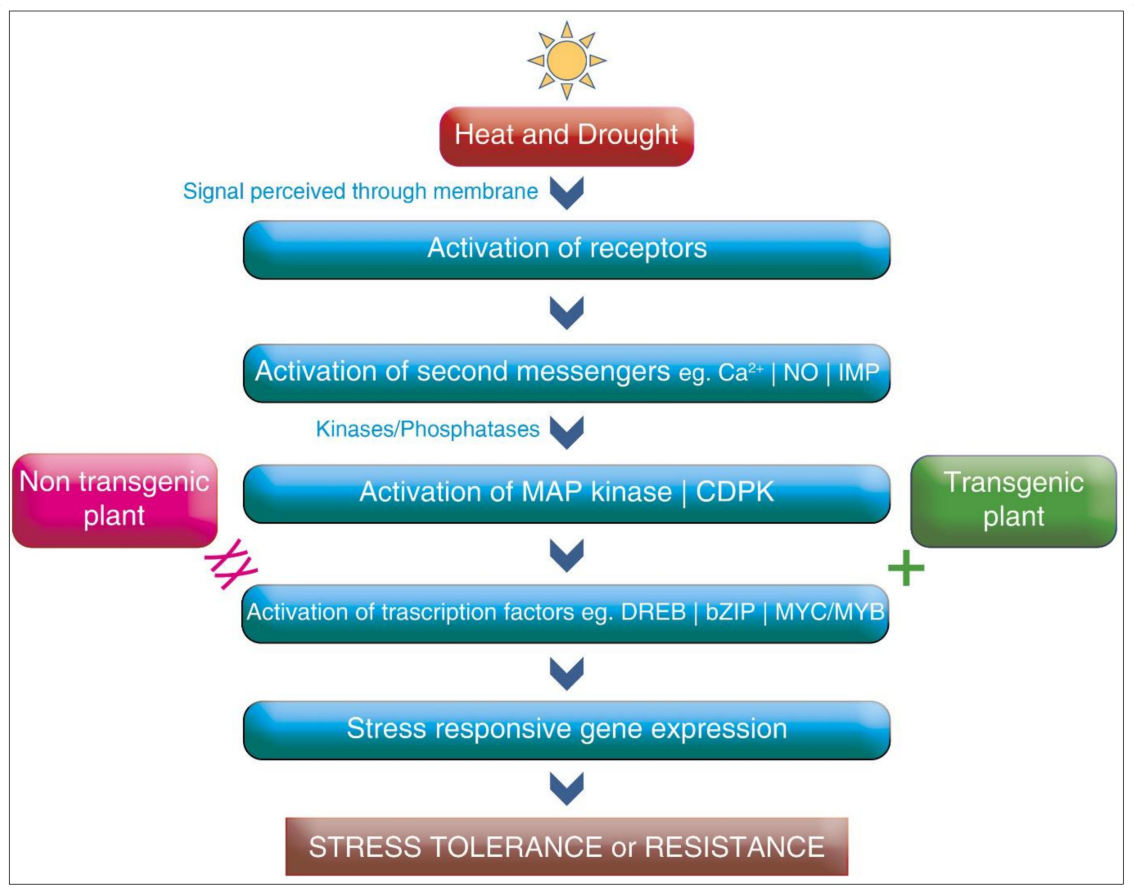

Figure 2. The basic mechanism of the transgenic approach during stress.

Sometimes heat stress impacts the electron transport system, and some studies have found that reduced electron flow between photosystems indirectly protects plants from photoinhibition [182,183]. Gosal et al. [184] reported the importance of the accumulation of LEA proteins in drought tolerance. The genes involved in the expression of LEA proteins, which help plants in maintaining the cell membrane structure and ionic balance under drought stress, have been developed [185]. The concept of the transgenic approach elucidates different candidate genes involved in response to complex abiotic stress in legume plants. Agrobacterium-mediated transformation or biolistic methods are some of the meth- 
ods by which transformation has been achieved for developing transgenic legumes. Past studies suggest that improved plant performance in drought conditions without having any negative impact on yield has been achieved with the incorporation of resistance genes into various genomes [183]. Legume plants that confer abiotic stress resistance have been genetically engineered that encode enzymes involved in the modification of membrane lipids and the biosynthesis of osmoprotectants and late embryogenesis proteins [186].

In response to complex stress environments, genes belonging to the AP2/ERF family and DREB transcription factors have a pivotal role in plant growth and development [187]. Genetic recombination and random mutagenesis are the major means of improvement of variability; however, it is a laborious process. With the rampant growth of the human population, in order to keep pace with rising food demands, crop improvement has to be advanced with newer technologies. One of the unique technologies for genetic manipulation, CRISPR/Cas9, has opened a new arena for the engineering of any genomic sequence with any target gene of interest more efficiently. The engineered CRISPR contains a guide RNA or single guide RNA (gRNA or sgRNA) and a CRISPR-associated endonuclease (Cas protein). The gRNA is a short synthetic RNA with a 20 nucleotides spacer and scaffold sequence necessary for Cas-binding. The gRNA base pairs with an RNA target, orienting bounds protein to carry out a site-specific cleavage, ligation, or modification reaction. Thus, one can change the genomic target of the Cas protein by simply changing the protein sequence present in the gRNA CRISPR/Cas9 is a more straightforward technology that does not fall under the regulatory monitoring mechanism as available for GM crops. This technology helps in the development of non-genetically modified plants, which are suitably edited with desired traits and can contribute to enhancing crop production under any stress (Figure 3).

A new study revealed that CRISPR/Cas9 mediated genome editing could be an essential technology to develop crops with improved tolerance to abiotic stresses [188]. In Leguminous crops, only a few studies have adopted CRISPR/Cas9 for editing drought tolerance-related genes. The first achieved success using CRISPR/Cas9-mediated gene editing was in soybeans, where a single sgRNA for transgene (bar) and six sgRNAs targeting various sites of two genes (GmSHR and GmFE12) were used [189]. CRISPR/Cas9 gene editing has huge potential for developing elite cultivars of legumes with durable and higher climate resilience by targeted and precise mutagenesis. Abiotic stress tolerant legumes developed through transgenic methods are listed in Table 5. Some of the genetic resources for cool-season legume crops in available gene banks are given in Table 6.

Table 5. Abiotic stress resistance in legumes.

\begin{tabular}{|c|c|c|c|c|}
\hline Transgenics & Gene Incorporated & Source & Stress Mitigated & References \\
\hline Soybean & $P 5 C R$ & Arabidopsis thaliana & Heat and drought stress & [190] \\
\hline Chickpea & P5CSF129A & & Increase in proline synthesis & [191] \\
\hline Chickpea & DREB1A & Arabidopsis thaliana & Drought tolerant & [187] \\
\hline Soybean & $L O S S / A B A 3$ & & Drought tolerant & [192] \\
\hline Cowpea & VuNCED1 & Vigna unguiculata & Drought tolerant & [193] \\
\hline Soybean & GmRACK1 & Glycine max & Drought tolerance during vegetative growth & [194] \\
\hline Soybean & AtABF3 & Arabidopsis thaliana & Enhance drought tolerance & [195] \\
\hline Chickpea & $\begin{array}{c}\text { DREB2A, MYB, } \\
\text { WRKY,bZIP,XPB1 }\end{array}$ & & Enhance tolerance to drought & [196] \\
\hline Chickpea & P5CSF129A & & Increase in proline synthesis & [191] \\
\hline Chickpea & DREB1A & Arabidopsis thaliana & Drought tolerant & [187] \\
\hline Soybean & LOSS/ABA3 & & Drought tolerant & [192] \\
\hline Cowpea & VuNCED1 & Vigna unguiculata & Drought tolerant & [193] \\
\hline Chickpea & CaP5CS & Cicer arietinum & Increases proline synthesis under water stress & [197] \\
\hline Alfalfa & $M n-S O D$ gene & $\begin{array}{c}\text { Nicotinia } \\
\text { plumbaginifolia }\end{array}$ & Drought tolerant & [198] \\
\hline Soybean & $\begin{array}{l}\text { Gm(DREB2, FDL19, SK1, } \\
\text { BIN2, NAC, DREB, ZIP) }\end{array}$ & Glycine max & Enhance drought tolerance & [199-203] \\
\hline
\end{tabular}


Table 6. Genetic resources of cool-season food legume in major gene banks.

\begin{tabular}{|c|c|c|c|}
\hline Crop & Gene Bank & Number & Source \\
\hline Lentil & Major gene banks of World & 58,405 & [204] \\
\hline Chick Pea & $>30$ countries of the world gene banks & $>80,000$ & CGIAR Gene bank database \\
\hline Lathyrus & ICARDA gene bank & 3315 & [205] \\
\hline Pea & $\begin{array}{l}16 \text { Major gene banks of world having } \\
\text { more than } 1000 \text { entry }\end{array}$ & 57,341 & [206] \\
\hline Faba Bean & ICARDA gene bank & 15,386 & [205] \\
\hline
\end{tabular}

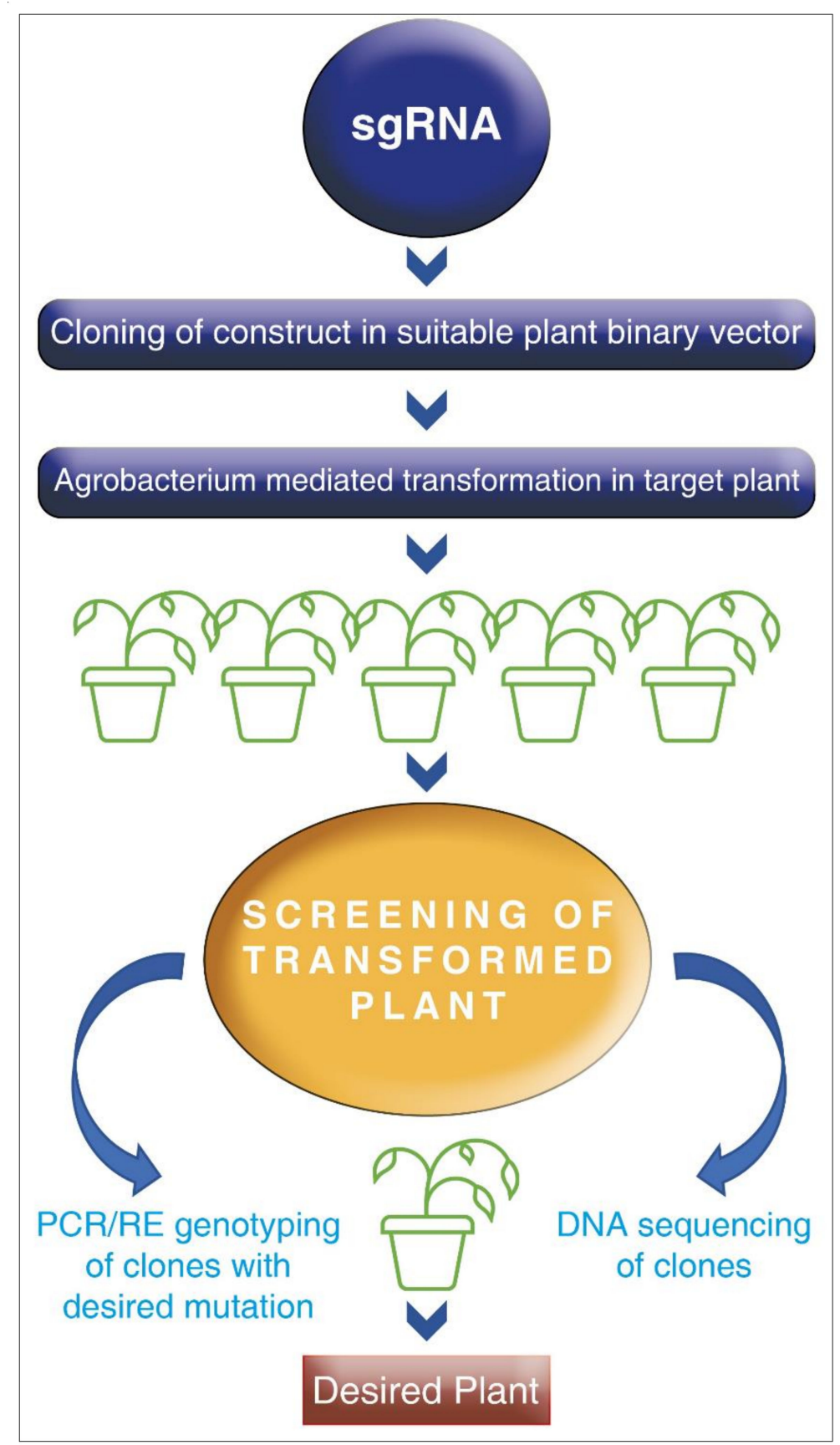

Figure 3. Schematic representation of genome editing (GE) using Cas9/sgRNA. 


\section{Conclusions}

The sustainable use of genetic resources for food and agriculture is the foundation of many of the climate change adoption strategies. The need for more farmer-friendly approaches and new genotypes adapted to stress is the need of the hour. The management approaches are not new; however, the time for implementing each approach and understanding crop responses is important. The breeding of adaptive traits is required for increasing the resilience of crops to current climate change conditions to help sustain productivity. To fast track the genetic gains with respect to stress in food legumes with the speed of climate change for crop improvement approaches like genomic assisted breeding, next generation of genomic assisted breeding approaches, data management, breeding programs, pre-breeding, and trait discovery are needed. The application of omics for understanding the molecular basis and plant response to temperature stress will pave the way for developing plants with better tolerance to temperature stress, ultimately leading to nutritional and food security.

Author Contributions: Conceptualization, V.V.K., A.R., R.V., P.B. and V.C.V.; writing-original draft preparation, V.V.K., A.R., R.V., P.B., V.C.V., A.N., M.P., B.M., A.G., M.H.R., M.A.S.C. and R.N.; writing-review and editing, M.S., M.B. and A.H.; funding acquisition, M.S., M.B. and A.H. All authors have read and agreed to the published version of the manuscript.

Funding: This research was funded by the 'Slovak University of Agriculture, Nitra, Tr. A. Hlinku 2,949 01 Nitra, Slovak Republic' under the project 'APVV-18-0465 and EPPN2020-OPVaI-VAITMS313011T813'.

Institutional Review Board Statement: Not applicable.

Informed Consent Statement: Not applicable.

Data Availability Statement: Not applicable.

Conflicts of Interest: The authors declare no conflict of interest.

\section{References}

1. Popelka, J.C.; Terryn, N.; Higgins, T.J.V. Gene technology for grain legumes: Can it contribute to the food challenge in developing countries? Plant Sci. 2004, 167, 195-206. [CrossRef]

2. Varshney, R.K.; Dubey, A. Novel genomic tools and modern genetic and breeding approaches for crop improvement. J. Plant Biochem. Biotechnol. 2009, 18, 127-138. [CrossRef]

3. Andrews, M.; Hodge, S. Climate change, a challenge for cool season grain legume crop production. In Climate Change and Management of Cool Season Grain Legume Crops; Springer: Dordrecht, The Netherlands, 2010; pp. 1-9.

4. Vijayan, R. Pulses: In need of more attention. Asian J. Biol. Sci. 2016, 11, 321-325. [CrossRef]

5. IPCC. Climate change. In Synthesis Report, Contribution of Working Group I, II and III to the Fifth Assessment Report of the InterGovernmental Panel on Climate Change; IPCC: Geneva, Switzerland, 2014; p. 151.

6. Jha, U.C.; Bohra, A.; Singh, N.P. Heat stress in crop plants: Its nature, impacts and integrated breeding strategies to improve heat tolerance. Plant Breed. 2014, 133, 679-701. [CrossRef]

7. Wahid, A.; Gelani, S.; Ashraf, M.; Foolad, M.R. Heat tolerance in plants: An overview. Environ. Exp. Bot. 2007, 61, 199-223. [CrossRef]

8. Hossain, A.; Skalicky, M.; Brestic, M.; Maitra, S.; Ashraful Alam, M.; Syed, M.A.; Hossain, J.; Sarkar, S.; Saha, S.; Bhadra, P.; et al. Consequences and Mitigation Strategies of Abiotic Stresses in Wheat (Triticum aestivum L.) under the Changing Climate. Agronomy 2021, 11, 241. [CrossRef]

9. Gaur, P.M.; Samineni, S.; Krishnamurthy, L.; Varshney, R.K.; Kumar, S.; Ghanem, M.E.; Nayyar, H. High temperature tolerance in grain legumes. Legume Perspect. 2015, 7, 23-24.

10. Vijayan, R.; Wani, S.H.; Rajendran, A.; Visha Kumari, V. Genetics and Breeding of Pulse Crops; Kalyani Publishers: New Delhi, India, 2018; p. 288.

11. Lipiec, J.; Doussan, C.; Nosalewicz, A.; Kondracka, K. Effect of drought and heat stresses on plant growth and yield: A review. Int. Agrophys. 2013, 27, 463-477. [CrossRef]

12. Hussain, M.; Malik, M.A.; Farooq, M.; Ashraf, M.Y.; Cheema, M.A. Improving drought tolerance by exogenous application of glycine betaine and salicylic acid in sunflower. J. Agron. Crop Sci. 2008, 194, 193-199. [CrossRef]

13. Rucker, K.S.; Kvien, C.K.; Holbrook, C.C.; Hook, J.E. Identification of peanut genotypes with improved drought avoidance traits. Peanut Sci. 1995, 22, 14-18. [CrossRef] 
14. Farooq, M.; Wahid, A.; Kobayashi, N.; Fujita, D.; Basra, S.M.A. Plant drought stress: Effects, mechanisms and management. Agron. Sustain. Dev. 2009, 29, 185-212. [CrossRef]

15. Praba, M.L.; Cairns, J.E.; Babu, R.C.; Lafitte, H.R. Identification of physiological traits underlying cultivar differences in drought tolerance in rice and wheat. J. Agron. Crop Sci. 2009, 195, 30-46. [CrossRef]

16. Ismail, A.M.; Hall, A.E. Reproductive-stage heat tolerance, leaf membrane thermo stability and plant morphology in cowpea. Crop Sci. 1999, 39, 1762-1768. [CrossRef]

17. Vollenweider, P.; Gunthardt-Goerg, M.S. Diagnosis of abiotic and biotic stress factors using the visible symptoms in foliage. Environ. Pollut. 2005, 137, 455-465. [CrossRef]

18. Fahad, S.; Hussain, S.; Saud, S.; Khan, F.; Hassan, S.; Nasim, W.; Huang, J. Exogenously applied plant growth regulators affect heat-stressed rice pollens. J. Agron. Crop Sci. 2016, 202, 139-150. [CrossRef]

19. Dreesen, P.E.; De Boeck, H.J.; Janssens, I.A.; Nijs, I. Summer heat and drought extremes trigger unexpeted changes in productivity of a temperate/biannual plant community. Environ. Exp. Bot. 2012, 79, 21-30. [CrossRef]

20. Rani, A.; Devi, P.; Jha, U.C.; Sharma, K.D.; Siddique, K.H.M.; Nayyar, H. Developing climate-resilient chickpea involving physiological and molecular approaches with a focus on temperature and drought stresses. Front. Plant Sci. 2020, 10, 1759. [CrossRef]

21. Choukri, H.; Hejjaoui, K.; El-Baouchi, A.; El haddad, N.; Smouni, A.; Maalouf, F.; Thavarajah, D.; Kumar, S. Heat and drought stress impact on phenology, grain yield, and nutritional quality of lentil (Lens culinaris Medikus). Front. Nutr. 2020, 7, 596307. [CrossRef]

22. Wei, Y.; Jin, J.; Jiang, S.; Ning, S.; Liu, L. Quantitative response of soybean development and yield to drought stress during different growth stages in the Huaibei Plain, China. Agronomy 2018, 8, 97. [CrossRef]

23. Kyei-boahen, S.; Savala, C.E.N.; Chikoye, D.; Abaidoo, R.; Kyei-Boahen, S. Growth and yield responses of cowpea to inoculation and phosphorus fertilization in different environments. Front. Plant Sci. 2017, 8, 646. [CrossRef]

24. Daryanto, S.; Wang, L.; Jacinthe, P.A. Global synthesis of drought effects on food legume production. PLoS ONE 2015, 10, e0127401. [CrossRef] [PubMed]

25. Kumar, K.; Solanki, S.; Singh, S.N.; Khan, M.A. Abiotic constraints of pulse production in India. In Disease of Pulse Crops and Their Sustainable Management; Biotech Books: New Delhi, India, 2016; pp. 23-39.

26. Lesk, C.; Rowhani, P.; Ramankutty, N. Influence of extreme weather disasters on global crop production. Nature 2016, 529, 84. [CrossRef] [PubMed]

27. Lobell, D.B.; Schlenker, W.; Costa-Roberts, J. Climate trends and global crop production since 1980. Science 2011, 333, 616-620. [CrossRef] [PubMed]

28. Challinor, A.J.; Watson, J.; Lobell, D.B.; Howden, S.M.; Smith, D.R.; Chhetri, N. A meta-analysis of crop yield under climate change and adaptation. Nat. Clim. Chang. 2014, 4, 287. [CrossRef]

29. Jisha, K.C.; Puthur, J.T. Seed priming with beta-amino butyric acid improves abiotic stress tolerance in rice seedlings. Rice Sci. 2016, 23, 242-254. [CrossRef]

30. Azadi, I.; Pezeshkpour, P.; Nasrollahi, H. Evaluation te effect of planting season and crop diversity of lentil (ghachsaran variety) in the dryland condition. J. Annu. Biol. Res. 2013, 4, 47-50.

31. Ruelland, E.; Zachowski, A. How plants sense temperature. Environ. Exp. Bot. 2010, 69, 225-232. [CrossRef]

32. Teixeira, R.N.; Ligterink, W.; Franca-Neto, J.D.B.; Hilhorst, H.W.; da Silva, E.A. Gene expression profiling of the green seed problem in soybean. BMC Plant Biol. 2016, 16, 37. [CrossRef]

33. Jagtap, V.; Bhargava, S.; Streb, P.; Feierabend, J. Comparative effect of water, heat and light stresses on photosynthetic reactions in Sorghum bicolor (L.) Moench. J. Exp. Bot. 1998, 49, 1715-1721.

34. Jiang, Y.; Huang, B. Drought and heat stress injury to two cool-season turf grasses in relation to antioxidant metabolism and lipid peroxidation. Crop Sci. 2001, 41, 436-442. [CrossRef]

35. Jiang, Y.; Huang, B. Effects of calcium on antioxidant activities and water relations associated with heat tolerance in two cool-season grasses. J. Exp. Bot. 2001, 52, 341-349. [CrossRef]

36. Brestic, M.; Zivcak, M.; Hauptvogel, P.; Misheva, S.; Kocheva, K.; Yang, X.; Li, X.; Allakhverdiev, S.I. Wheat plant selection for high yields entailed improvement of leaf anatomical and biochemical traits including tolerance to non-optimal temperature conditions. Photosynth. Res. 2018, 136, 245-255. [CrossRef]

37. Kaushal, N.; Awasthi, R.; Gupta, K.; Gaur, P.; Siddique, K.H.; Nayyar, H. Heat-stress-induced reproductive failures in chickpea (Cicer arietinum) are associated with impaired sucrose metabolism in leaves and anthers. Funct. Plant Biol. 2013, 40, 1334-1349. [CrossRef]

38. Kumar, S.; Thakur, P.; Kaushal, N.; Malik, J.A.; Gaur, P.; Nayyar, H. Effect of varying high temperatures during reproductive growth on reproductive function, oxidative stress and seed yield in chickpea genotypes differing in heat sensitivity. Arch. Agron. Soil Sci. 2013, 59, 823-843. [CrossRef]

39. Guilioni, L.; Wery, J.; Tardieu, F. Heat stress-induced abortion of buds and flowers in pea: Is sensitivity linked to organ age or to relations between reproductive organs? Ann. Bot. 1997, 80, 159-168. [CrossRef]

40. Devasirvatham, V.; Gaur, P.M.; Mallikarjuna, N.; Raju, T.N.; Trethowan, R.M.; Tan, D.K. Reproductive biology of chickpea response to heat stress in the field is associated with the performance in controlled environments. Field Crops Res. 2013, 142, 9-19. [CrossRef] 
41. Kaushal, N.; Bhandari, K.; Siddique, K.H.; Nayyar, H. Food crops face rising temperatures: An overview of responses, adaptive mechanisms, and approaches to improve heat tolerance. Cogent Food Agric. 2016, 2, 1134380. [CrossRef]

42. Gross, Y.; Kigel, J. Differential sensitivity to high temperature of stages in the reproductive development of common bean (Phaseolus vulgaris L.). Field Crops Res. 1994, 36, 201-212. [CrossRef]

43. Nakano, H.; Kobayashi, M.; Terauchi, T. Sensitive stages to heat stress in pod setting of common bean (Phaseolus vulgaris L.). J. Trop. Agric. 1998, 42, 78-84.

44. Maheswari, M.; Sarkar, B.; Vanaja, M.; Srinivasa Rao, M.; Srinivasa Rao, C. Food production under aberrant weather conditions In Technical Bulletin; Central Research Institute for Dry land Agriculture (ICAR): Hyderabad, India, 2015; p. 47.

45. Liu, X.; Huang, B. Heat stress injury in relation to membrane lipid peroxidation in creeping bentgrass. Crop Sci. 2000, 40, 503-510. [CrossRef]

46. Moran, J.F.; Becana, M.; Iturbe-Ormaetxe, I.; Frechilla, S.; Klucas, R.V.; Aparicio-Tejo, P. Drought induces oxidative stress in pea plants. Planta 1994, 194, 346-352. [CrossRef]

47. Ludlow, M.M.; Muchow, R.C. A critical evaluation of traits for improving crop yields in water-limited environments. Adv. Agron. 1990, 43, 107-153.

48. Maroco, J.P.; Pereira, J.S.; Chaves, M.M. Stomatal responses to leaf-to-air vapour pressure deficit in Sahelian species. Funct. Plant Biol. 1997, 24, 381-387. [CrossRef]

49. Turner, N.C.; Wright, G.C.; Siddique, K.H.M. Adaptation of grain legumes (pulses) to water-limited environments. Adv. Agron. 2001, 71, 193-231.

50. Lawlor, D.W.; Cornic, G. Photosynthetic carbon assimilation and associated metabolism in relation to water deficits in higher plants. Plant. Cell Environ. 2002, 25, 275-294. [CrossRef]

51. Kadiyala, M.D.M.; Kumara Charyulu, D.; Nedumaran, S.; D Shyam, M.; Gumma, M.K.; Bantilan, M.C.S. Agronomic management options for sustaining chickpea yield under climate change scenario. J. Agrometeorol. 2016, 18, 41-47.

52. Bishop, J.; Potts, S.G.; Jones, H.E. Susceptibility of faba bean (Vicia faba L.) to heat stress during floral development and anthesis. J. Agron. Crop Sci. 2016, 202, 508-517. [CrossRef]

53. Sehgal, A.; Sita, K.; Kumar, J.; Kumar, S.; Singh, S.; Siddique, K.H.M.; Nayyar, H. Effects of drought, heat and their interaction on the growth, yield and photosynthetic function of lentil (Lens culinaris Medikus) genotypes varying in heat and drought sensitivity. Front. Plant Sci. 2017, 8, 1776. [CrossRef]

54. Podleśny, J.; Podlenesa, A. The effect of high temperature during flowering on growth, development and yielding of blue lupine-barley mixture. J. Food Agric. Environ. 2012, 10, 500-504.

55. Vijaylaxmi. Effect of high temperature on growth, biomass and yield of field pea genotypes. Legume Res. 2013, 36, 250-254.

56. Awasthi, R.; Kaushal, N.; Vadez, V.; Turner, N.C.; Berger, J.; Siddique, K.H.; Nayyar, H. Individual and combined effects of transient drought and heat stress on carbon assimilation and seed filling in chickpea. Funct. Plant Biol. 2014, 41, 1148-1167. [CrossRef] [PubMed]

57. Hall, A.E. Breeding for adaptation to drought and heat in cowpea. Eur. J. Agron. 2004, 21, 447-454. [CrossRef]

58. Canci, H.; Toker, C. Evaluation of yield criteria for drought and heat resistance in chickpea (Cicer arietinum L.). J. Agron. Crop Sci. 2009, 195, 47-54. [CrossRef]

59. Kumar, J.; Kant, R.; Kumar, S.; Basu, P.S.; Sarker, A.; Singh, N.P. Heat tolerance in lentil under field conditions. Legume Genom. Genet. 2016, 7, 1-11.

60. Boote, K.J.; Allen, L.H.; Prasad, P.V.; Baker, J.T.; Gesch, R.W.; Snyder, A.M.; Thomas, J.M. Elevated temperature and CO $\mathrm{CO}_{2}$ impacts on pollination, reproductive growth, and yield of several globally important crops. J. Agric. Meteorol. 2005, 60, 469-474. [CrossRef]

61. Nicolas, M.E.; Gleadow, R.M.; Dalling, M.J. Effect of post-anthesis drought on cell division and starch accumulation in developing wheat grains. Ann. Bot. 1985, 55, 433-444. [CrossRef]

62. Siddique, K.H.M.; Loss, S.P.; Regan, K.L.; Jettner, R.L. Adaptation and seed yield of cool season grain legumes in Mediterranean environments of south-western Australia. Aust. J. Agric. Res. 1999, 50, 375-388. [CrossRef]

63. Bhandari, K.; Siddique, K.H.; Turner, N.C.; Kaur, J.; Singh, S.; Agrawal, S.K.; Nayyar, H. Heat stress at reproductive stage disrupts leaf carbohydrate metabolism, impairs reproductive function, and severely reduces seed yield in lentil. J. Crop Improv. 2016, 30, 118-151. [CrossRef]

64. Sita, K.; Sehgal, A.; Rao, B.H.; Nair, R.M.; Vara Prasad, P.V.; Kumar, S.; Nayyar, H. Food legumes and rising temperatures: Effects, adaptive functional mechanisms specific to reproductive growth stage and strategies to improve heat tolerance. Front. Plant Sci. 2017, 8, 1658 .

65. Downes, R.W.; Gladstones, J.S. Physiology of growth and seed production in Lupin usangustifolius L. I. Effects on pod and seed set of controlled short duration high temperatures at flowering. Crop Pasture Sci. 1984, 35, 493-499. [CrossRef]

66. Jiang, Y.; Lahlali, R.; Karunakaran, C.; Kumar, S.; Davis, A.R.; Bueckert, R.A. Seed set, pollen morphology and pollen surface composition response to heat stress in field pea. Plant Cell Environ. 2015, 38, 2387-2397. [CrossRef] [PubMed]

67. Waraich, E.A.; Ahmad, R.; Halim, A.; Aziz, T. Alleviation of temperature stress by nutrient management in crop plants: A review. J. Soil Sci. Plant Nutr. 2012, 12, 221-244. [CrossRef]

68. Visha Kumari, V.; Hoekenga, O.; Salini, K.; Chandran, M.A.S. Biofortification of food crops in India: An Agricultural Perspective. Asian Biotech. Dev. Rev. 2014, 16, 21-41.

69. Broadley, M.R.; White, P.J.; Hammond, J.P.; Zelko, I.; Lux, A. Zinc in plants. New Phytol. 2007, 173, 677-702. [CrossRef] 
70. Sharma, P.N.; Chatterjee, C.; Agarwala, S.C.; Sharma, C.P. Zinc deficiency and pollen fertility in maize (Zea mays). In Plant Nutrition-Physiology and Applications; Springer: Dordrecht, The Netherlands, 1990; pp. 261-265.

71. Pandey, N.; Gupta, M.; Sharma, C.P. SEM studies on Zn deficient pollen and Stigma of Vicia faba. Phytomorphology 1995, 45, 169-173.

72. Pandey, N.; Pathak, G.C.; Sharma, C.P. Zinc is critically required for pollen function and fertilization in lentil. J. Trace Elem. Biol. 2006, 20, 89-96. [CrossRef]

73. Rout, G.R.; Sahoo, S. Role of iron in plant growth and metabolism. Rev. Agric. Sci. 2015, 3, 1-24. [CrossRef]

74. Briat, J.F.; Fobis-Loisy, I.; Grignon, N.; Lobréaux, S.; Pascal, N.; Savino, G.; Thoiron, S.; Von Wirén, N.; Van Wuytswinkel, O. Cellular and molecular aspects of iron metabolism in plants. Biol. Cell 1995, 84, 69-81. [CrossRef]

75. Dear, B.S.; Lipsett, J. The effect of boron supply on the growth and seed production of sub-terranean clover (Trifoliumsubterraneum L.). Aust. J. Agric. Res. 1987, 38, 537-546. [CrossRef]

76. Dell, B.; Huang, L. Physiological response of plants to low boron. Plant Soil 1997, 193, 103-120. [CrossRef]

77. Xu, H.; Huang, Q.; Shen, K.; Shen, Z. Anatomical studies on the effects of boron on the development of stamen and pistil of rape (Brassica napus L.). Zhiwu Xuebao 1993, 35, 453-457.

78. Visha Kumari, V.; Banerjee, P.; Nath, R.; Sengupta, K.; Sarath Chandran, M.A.; Kumar, R. Effect of foliar spray on phenology and yield of Lentil sown on different dates. J. Crop Weed 2019, 15, 54-58. [CrossRef]

79. Rademacher, W. Plant growth regulators: Backgrounds and uses in plant production. J. Plant Growth Regul. 2015, 34, 845-872. [CrossRef]

80. Oshino, T.; Miura, S.; Kikuchi, S.; Hamada, K.; Yano, K.; Watanabe, M.; Higashitani, A. Auxin depletion in barley plants under high-temperature conditions represses DNA proliferation in organelles and nuclei via transcriptional alterations. Plant Cell Environ. 2011, 34, 284-290. [CrossRef] [PubMed]

81. Zhang, M.; Duan, L.; Zhai, Z.; Li, J.; Tian, X.; Wang, B.; Li, Z. Effects of plant growth regulators on water deficit-induced yield loss in soybean. In Proceedings of the 4th International Crop Science Congress, Brisbane, Australia, 26 Sepember-1 October 2004; pp. 252-256.

82. Hedden, P.; Thomas, S.G. Gibberellin biosynthesis and its regulation. Biochem. J. 2012, 444, 11-25. [CrossRef]

83. Kumar, S.; Kaushal, N.; Nayyar, H.; Gaur, P. Abscisic acid induces heat tolerance in chickpea (Cicer arietinum L.) seedlings by facilitated accumulation of osmo-protectants. Acta Physiol. Plant. 2012, 34, 1651-1658. [CrossRef]

84. Saleh, A.A.; Abdel-Kader, D.Z.; El Elish, A.M. Role of heat shock and salicylic acid in antioxidant homeostasis in Mungbean (Vigna radiata L.) plant subjected to heat stress. J. Plant Physiol. 2007, 2, 344-355. [CrossRef]

85. Khan, N.; Bano, A.M.D.; Babar, A. Impacts of plant growth promoters and plant growth regulators on rainfed agriculture. PLoS ONE 2020, 15, e0231426. [CrossRef]

86. Rady, M.M.; Boriek, S.H.K.; Abd El-Mageed, T.A.; Seif El-Yazal, M.A.; Ali, E.F.; Hassan, F.A.S.; Abdelkhalik, A. Exogenous Gibberellic Acid or Dilute Bee Honey Boosts Drought Stress Tolerance in Vicia faba by Rebalancing Osmoprotectants, Antioxidants, Nutrients, and Phytohormones. Plants 2021, 10, 748. [CrossRef] [PubMed]

87. Molla, M.R.; Ali, M.R.; Hasanuzzaman, M.; Al-Mamun, M.H.; Ahmed, A.; Nazim-Ud-Dowla, M.; Rohman, M.M. Exogenous proline and betaine-induced upregulation of glutathione transferase and glyoxalase I in lentil (Lens culinaris) under drought Stress. Not. Bot. Horti Agrobot. Cluj Napoca 2014, 42, 73-80. [CrossRef]

88. Garg, P.; Hemantaranjan, A.; Pradhan, J. Mitigation effects of 24-epibrassinolide and thiourea in field pea (Pisum sativum L.) under drought stress. J. Plant. Sci. Res. 2018, 34, 227-233. [CrossRef]

89. Seleiman, M.F.; Al-Suhaibani, N.; Ali, N.; Akmal, M.; Alotaibi, M.; Refay, Y.; Dindaroglu, T.; Abdul-Wajid, H.H.; Battaglia, M.L. Drought stress impacts on plants and different approaches to alleviate its adverse effects. Plants 2021, 10, 259. [CrossRef] [PubMed]

90. Taylor, A.G.; Harman, G.E. Concepts and technologies of selected seed treatments. Annu. Rev. Phytopathol. 1990, 28, 321-339. [CrossRef]

91. Kubala, S.; Wojtyla, L.; Quinet, M.; Lechowska, K.; Lutts, S.; Garnczarska, M. Enhanced expression of the proline synthesis gene P5CSA in relation to seed osmo-priming improvement of Brassica napus germination under salinity stress. J. Plant Physiol. 2015, 183, 1-12. [CrossRef]

92. Iqbal, M.; Ashraf, M. Wheat seed priming in relation to salt tolerance: Growth, yield and levels of free salicylic acid and polyamines. Ann. Bot. Fenn. 2006, 43, 250-259.

93. Ghassemi-Golezani, K.; Aliloo, A.A.; Valizadeh, M.; Moghaddam, M. Effects of different priming techniques on seed invigoration and seedling establishment of lentil (Lens culinaris Medik). J. Food Agric. Environ. 2008, 6, 222-226.

94. Mukundam, B.; Ramana, M.V.; Lakshmi, C.S.; Raja, V. Effect of tillage practices and seed priming on growth and yield of upland crops in rice fallows-A review. Agric. Rev. 2008, 29, 74-78.

95. Yucel, D.O. The effect of different priming treatments and germination temperatures on germination performance of lentil (Lens culinaris Medik) seeds. J. Agric. Biol. Sci. 2012, 7, 977-981.

96. Ghasemi-Golezani, K.; Japparpour-Bonyadi, Z.; Shafagh-Kolvanagh, J.; Nikpour-Rashidabad, N. Effects of water stress and hydro-priming duration on field performance of lentil. Int. J. Farming Allied Sci. 2013, 2, 922-925.

97. Pakbaz, N.; Barary, M.; Mehrabi, A.A.; Hatami, A. Effect of seed priming on growth and yield of lentil (Lens culinaris L.) genotypes under rainfed and supplemental irrigation conditions. Int. J. Biosci. 2014, 5, 131-139. 
98. Aliloo, A.A.; Alahyari, S.; Mosavi, S.B. Micronutrient priming improves germination and seedling establishment in lentil. Adv. Appl. Agric. Sci. 2014, 11, 37-44.

99. Kumar, P.M.; Chaurasia, A.K.; Michael Bara, B.M. Effect of osmo-priming on seed germination behaviour and vigour of chickpea (Cicer arietinum L.). Int. J. Sci. Nat. 2017, 8, 330-335.

100. Harris, D.B.S.R.; Raghuwanshi, B.S.; Gangwar, J.S.; Singh, S.C.; Joshi, K.D.; Rashid, A.; Hollington, P.A. Participatory evaluation by farmers of on-farm seed priming in wheat in India, Nepal and Pakistan. Exp. Agric. 2001, 37, 403-415. [CrossRef]

101. Harris, D.; Joshi, A.; Khan, P.A.; Gothkar, P.; Sodhi, P.S. On-farm seed priming in semi-arid agriculture: Development and evaluation in maize, rice and chickpea in India using participatory methods. Exp. Agric. 1999, 35, 15-29. [CrossRef]

102. Kaur, S.; Gupta, A.K.; Kaur, N. Seed priming increases crop yield possibly by modulating enzymes of sucrose metabolism in chickpea. J. Agron. Crop Sci. 2005, 191, 81-87. [CrossRef]

103. Afzal, I.; Rehman, H.U.; Naveed, M.; Basra, S.M.A. Recent advances in seed enhancements. In New Challenges in Seed Biology-Basic and Translational Research Driving Seed Technology; In Tech Open Limited: London, UK, 2016; pp. 47-74.

104. Uddin, M.J.; Ali, M.O.; Rahman, M.M. Prospects of chickpea in rice-based cropping systems in Bangladesh. In Proceedings of the Policy and Strategy for Increasing Income and Food Security through Improved Crop Management of Chickpea in Rice Fallows in Asia, Kathmandu, Nepal, 17-18 November 2004; Summary of a NARC-ICRISAT-NRI Workshop; Patancheru 502 324; International Crops Research Institute for the Semi-Arid Tropics: Andhra Pradesh, India, 2005; Volume 156, pp. 35-46.

105. Padgham, J. Agricultural development under a changing climate: Opportunities and challenges for adaptation. In Joint Departmental Discussion Paper -Issue 1; Agriculture and Rural Development \& Environment Departments, The International Bank for Reconstruction and Development, The World Bank: Washington, DC, USA, 2009; p. 169.

106. Bhowmick, M.K. Seed Priming: A Low-Cost Technology for Resource-Poor Farmers in Improving Pulse Productivity. In Advances in Seed Priming; Springer: Singapore, 2018; pp. 187-208.

107. Ashraf, M.; Foolad, M.R. Pre-sowing seed treatment-A shotgun approach to improve germination, plant growth, and crop yield under saline and non-saline conditions. Adv. Agron. 2005, 88, 223-271.

108. Patade, V.Y.; Bhargava, S.; Suprasanna, P. Halo-priming imparts tolerance to salt and PEG induced drought stress in sugarcane. Agric. Ecosyst. Environ. 2009, 134, 24-28. [CrossRef]

109. Jisha, K.C.; Vijayakumari, K.; Puthur, J.T. Seed priming for abiotic stress tolerance: An overview. Acta Physiol. Plant. 2013, 35, 1381-1396. [CrossRef]

110. Jisha, K.C.; Puthur, J.T. Seed priming with BABA ( $\beta$-amino butyric acid): A cost-effective method of abiotic stress tolerance in Vignaradiata (L.) Wilczek. Protoplasma 2016, 253, 277-289. [CrossRef]

111. Musa, A.M.; Harris, D.; Johansen, C.; Kumar, J.V.D.K. Short duration chickpea to replace fallow after aman rice: The role of on-farm seed priming in the High Barind Tract of Bangladesh. Exp. Agric. 2001, 37, 509-521. [CrossRef]

112. Kaya, M.D.; Okcu, G.; Atak, M.; Cikili, Y.; Kolsarici, O. Seed treatments to overcome salt and drought stress during germination in sunflower (Helianthus annuus L.). Eur. J. Agron. 2006, 24, 291-295. [CrossRef]

113. Farooq, M.; Basra, S.M.A.; Rehman, H.; Saleem, B.A. Seed priming enhances the performance of late sown wheat (Triticumaestivum L.) by improving chilling tolerance. J. Agron. Crop Sci. 2008, 194, 55-60. [CrossRef]

114. Farooq, M.; Basra, S.M.; Wahid, A.; Ahmad, N. Changes in nutrient-homeostasis and reserves metabolism during rice seed priming: Consequences for seedling emergence and growth. Agric. Sci. China 2010, 9, 191-198. [CrossRef]

115. Jafar, M.Z.; Farooq, M.; Cheema, M.A.; Afzal, I.; Basra, S.M.A.; Wahid, M.A.; Shahid, M. Improving the performance of wheat by seed priming under saline conditions. J. Agron. Crop Sci. 2012, 198, 38-45. [CrossRef]

116. Solaimalai, A.; Subburamu, K. Seed hardening for field crops-A review. Agric. Rev. 2004, 25, 129-140.

117. Cohen, Y. The BABA story of induced resistance. Phytoparasitica 2001, 29, 375-378. [CrossRef]

118. Jakab, G.; Cottier, V.; Toquin, V.; Rigoli, G.; Zimmerli, L.; Metraux, J.P.; Mauch-Mani, B. D-Aminobutyric acid-induced resistance in plants. Eur. J. Plant Pathol. 2001, 107, 29-37. [CrossRef]

119. Jakab, G.; Ton, J.; Flors, V.; Zimmerli, L.; Metraux, J.P.; Mauch-Mani, B. Enhancing Arabidopsis salt and drought stress tolerance by chemical priming for its abscisic acid responses. Plant Physiol. 2005, 139, 267-274. [CrossRef]

120. Zimmerli, L.; Hou, B.H.; Tsai, C.H.; Jakab, G.; Mauch-Mani, B.; Somerville, S. The xenobiotic $\beta$-aminobutyric acid enhances Arabidopsis thermo-tolerance. Plant J. 2008, 53, 144-156. [CrossRef]

121. Ton, J.; Jakab, G.; Toquin, V.; Flors, V.; Iavicoli, A.; Maeder, M.N.; Mauch-Mani, B. Dissecting the $\beta$-aminobutyric acid-induced priming phenomenon in Arabidopsis. Plant Cell 2005, 17, 987-999. [CrossRef]

122. Kohler, J.; Hernandez, J.A.; Caravaca, F.; Roldan, A. Plant-growth-promoting rhizobacteria and arbuscular mycorrhizal fungi modify alleviation biochemical mechanisms in water-stressed plants. Funct. Plant Biol. 2008, 35, 141-151. [CrossRef]

123. Saravanakumar, D.; Kavino, M.; Raguchander, T.; Subbian, P.; Samiyappan, R. Plant growth promoting bacteria enhance water stress resistance in green gram plants. Acta Physiol. Plant. 2011, 33, 203-209. [CrossRef]

124. Bharti, N.; Pandey, S.S.; Barnawal, D.; Patel, V.K.; Kalra, A. Plant growth promoting rhizo bacteria Dietzia natronolimnaea modulates the expression of stress responsive genes providing protection of wheat from salinity stress. Sci. Rep. 2016, 6, 34768. [CrossRef]

125. Habib, S.H.; Kausar, H.; Saud, H.M. Plant growth-promoting rhizobacteria enhance salinity stress tolerance in okra through ROS-scavenging enzymes. Biol. Med. Res. Int. 2016, 2016, 6284547. [CrossRef] [PubMed]

126. Gangwar, K.S.; Singh, K.K.; Sharma, S.K.; Tomar, O.K. Alternative tillage and crop residue management in wheat after rice in sandy loam soils of Indo-Gangetic plains. Soil Till Res. 2006, 88, 242-252. [CrossRef] 
127. Kar, G.; Kumar, A. Evaluation of post-rainy season crops with residual soil moisture and different tillage methods in rice fallow of eastern India. Agric. Water Manag. 2009, 96, 931-938. [CrossRef]

128. Layek, J.; Chowdhury, S.; Ramkrushna, G.I.; Das, A. Evaluation of different lentil cultivars in lowland rice fallow under no-till system for enhancing cropping intensity and productivity. Indian J. Hill Farming 2014, 27, 4-9.

129. Ghosh, P.K.; Das, A.; Saha, R.; Kharkrang, E.; Tripathi, A.K.; Munda, G.C.; Ngachan, S.V. Conservation agriculture towards achieving food security in North East India. Curr. Sci. 2010, 99, 915-921.

130. Mishra, J.P.; Praharaj, C.S.; Singh, K.K. Enhancing water use efficiency and production potential of chickpea and field pea through seed bed configurations and irrigation regimes in North Indian Plains. J. Food Legume 2012, 25, 310-313.

131. Reddy, A.A. Pulses production technology: Status and way forward. Econ. Polit. Wkly. 2009, 44, 73-80. [CrossRef]

132. Kumar, N.; Hazra, K.K.; Singh, S.; Nadarajan, N. Constraints and Prospects of growing pulses in rice fallows of India. Indian Farming 2016, 66, 13-16.

133. Castillo, A.G.; Hampton, J.G.; Coolbear, P. Effect of population density on within canopy environment and seed vigour in garden pea (Pisum sativum L.). Proc. Agron. Soc. N. Z. 1993, 23, 99-106.

134. Patel, H.R.; Patel, F.H.; Maheriya, V.D.; Dodia, I.N. Response of kharif green gram (Vigna radiate L.) to sulphur and phosphorous with and without biofertilizer application. Bioscan 2013, 8, 149-152.

135. Kajla, M.; Yadav, V.K.; Chhokar, R.S.; Sharma, R.K. Management practices to mitigate the impact of high temperature on wheat. J. Wheat Res. 2015, 7, 1-12.

136. Khan, N.; Bano, A.; Babar, M.A. Metabolic and physiological changes induced by plant growth regulators and plant growth promoting rhizobacteria and their impact on drought tolerance in Cicer arietinum L. PLoS ONE 2019, 14, e0213040. [CrossRef]

137. Glick, B.R.; Cheng, Z.; Czarny, J.; Duan, J. Promotion of plant growth by ACC deaminase producing soil bacteria. In New Perspectives and Approaches in Plant Growth-Promoting Rhizo-Bacteria Research; Springer: Dordrecht, The Netherlands, 2007; pp. 329-339.

138. Niu, X.; Song, L.; Xiao, Y.; Ge, W. Drought-tolerant plant growth-promoting rhizobacteria associated with foxtail millet in a semi-arid agro-ecosystem and their potential in alleviating drought stress. Front. Microbiol. 2018, 8, 2580. [CrossRef]

139. Belimov, A.A.; Dodd, I.C.; Hontzeas, N.; Theobald, J.C.; Safronova, V.I.; Davies, W.J. Rhizosphere bacteria containing 1aminocyclopropane-1-carboxylate deaminase increase yield of plants grown in drying soil via both local and systemic hormone signalling. New Phytol. 2009, 181, 413-423. [CrossRef]

140. Dimkpa, C.; Weinand, T.; Asch, F. Plant-rhizobacteria interactions alleviate abiotic stress conditions. Plant Cell Environ. 2009, 32, 1682-1694. [CrossRef]

141. Chanway, C.P.; Hynes, R.K.; Nelson, L.M. Plant growth-promoting rhizobacteria: Effects on growth and nitrogen fixation of lentil (Lens esculenta Moench) and pea (Pisumsativum L.). Soil Biol. Biochem. 1989, 21, 511-517. [CrossRef]

142. Auge, R.M. Water relations, drought and vesicular-arbuscular mycorrhizal symbiosis. Mycorrhiza 2001, 11, 3-42. [CrossRef]

143. Habibzadeh, Y.; Evazi, A.R.; Abedi, M. Alleviation drought stress of mungbean (Vigna radiata L.) plants by using arbuscular mycorrhizal fungi. Int. J. Agric. Sci. Nat. Res. 2014, 1, 1-6.

144. Smith, S.E.; Facelli, E.; Pope, S.; Smith, F.A. Plant performance in stressful environments: Interpreting new and established knowledge of the roles of arbuscular mycorrhizas. Plant Soil 2010, 326, 3-20. [CrossRef]

145. Stoddard, F.L.; Balko, C.; Erskine, W.; Khan, H.R.; Link, W.; Sarker, A. Screening techniques and sources of resistance to abiotic stresses in cool-season food legumes. Euphytica 2006, 147, 167-186. [CrossRef]

146. Barnabás, B.; Jäger, K.; Fehér, A. The effect of drought and heat stress on reproductive processes in cereals. Plant Cell Environ. 2008, 31, 11-38. [CrossRef]

147. Odeny, D.A. The potential of pigeonpea (Cajanus cajan(L.) Millsp.) in Africa. Nat. Resour. Forum 2007, 31, 297-305. [CrossRef]

148. Berger, J.D.; Milroy, S.P.; Turner, N.C.; Siddique, K.H.M.; Imtiaz, M.; Malhotra, R. Chickpea evolution has selected for contrasting phenological mechanisms among different habitats. Euphytica 2011, 180, 1-15. [CrossRef]

149. Hamdi, A.; Erskine, W. Reaction of wild species of the genus Lens to drought. Euphytica 1996, 91, 173-179.

150. Solanki, R.K.; Gill, R.K.; Verma, P.; Singh, S. Mutation breeding in pulses: An overview. In Breeding of Pulse Crops; Khan, S., Kozgar, M.I., Eds.; Kalyani Publishers: Ludhiana, India, 2011; pp. 85-103.

151. Darai, R.; Ojha, B.R.; Sarker, A.; Sah, R. Genetics and Breeding for Drought Tolerance in Food Legumes. Int. J. Environ. Agric. Biol. 2016, 1. [CrossRef]

152. Hatfield, J.L.; Boote, K.J.; Kimball, B.A.; Ziska, L.H.; Izaurralde, R.C.; Ort, D.R.; Thomson, A.M.; Wolfe, D. Climate impacts on agriculture: Implications for crop production. BMC Genom. 2011, 10, 523. [CrossRef]

153. Sambatti, J.B.M.; Caylor, K.K. When breeding for drought tolerance is is optimal if drought is random? New Physiol. 2007, 175, 70-80. [CrossRef]

154. Sehgal, A.; Sita, K.; Siddique, K.H.M.; Kumar, R.; Bhogireddy, S.; Varshney, R.K.; Rao, B.H.; Nair, R.M.; Prasad, P.V.V.; Nayyar, H. Drought or/and Heat-Stress Effects on Seed Filling in Food Crops: Impacts on Functional Biochemistry, Seed Yields, and Nutritional Quality. Front. Plant Sci. 2018, 9, 1705. [CrossRef]

155. Brestic, M.; Zivcak, M.; Kunderlikova, K.; Allakhverdiev, S.I. High temperature specifically affects the photoprotective responses of chlorophyll b-deficient wheat mutant lines. Photosynth. Res. 2016, 130, 251-266. [CrossRef] [PubMed]

156. Fleury, D.; Jefferies, S.; Kuchel, H.; Langridge, P. Genetic and genomic tools to improve drought tolerance in wheat. J. Exp. Bot. 2010, 61, 3211-3222. [CrossRef] 
157. Bita, C.E.; Gerats, T. Plant tolerance to high temperature in a changing environment: Scientific fundamentals and production of heat tolerance crops. Front. Plant Sci. 2013, 4, 273. [CrossRef] [PubMed]

158. Barik, S.; Rai, N.; Mishra, P.; Singh, S.K.; Gautam, V. Bioinformatics: How it helps to boost modern biological research. Curr. Sci. 2020, 118, 698-699.

159. Kashiwagi, J.; Krishnamurthy, L.; Crouch, J.H.; Serraj, R. Variability of root length density and its contributions to seed yield in chickpea (Cicer arietinum L.) under terminal drought stress. Field Crops Res. 2006, 95, 171-181. [CrossRef]

160. Varshney, R.K.; Pazhamala, L.; Kashiwagi, J.; Gaur, P.M.; Krishnamurthy, L.; Hoisington, D.A. Genomics and physiological approaches for root trait breeding to improve drought tolerance in chickpea (Cicer arietinum L.). In Root Genomics; De Oliveira, A.D., Varshney, R.K., Eds.; Springer: Berlin/Heidelberg, Germany, 2011; pp. 233-250.

161. Varshney, R.K.; Thudi, M.; Nayak, S.N.; Gaur, P.M.; Kashiwagi, J.; Krishnamurthy, L.; Jaganathan, D.; Koppolu, J.; Bohra, A.; Tripathi, S.; et al. Genetic dissection of drought tolerance in chickpea (Cicerarietinum L.). Theor. Appl. Genet. 2014, 127, 445-462. [CrossRef] [PubMed]

162. Langridge, P.; Fleury, D. Making the most of 'omics' for crop breeding. Trends Biotechnol. 2011, 29, 33-40. [CrossRef]

163. Valliyodan, B.; Nguyen, H.T. Understanding regulatory networks and engineering for enhanced drought tolerance in plants. Curr. Opin. Plant Biol. 2006, 9, 189-195. [CrossRef]

164. Kudapa, H.; Garg, V.; Chitikineni, A.; Varshney, R.K. The RNA-Seqbased high resolution gene expression atlas of chickpea (Cicer arietinum L.) reveals dynamic spatio-temporal changes associated with growth and development. Plant Cell Environ. 2018, 41, 2209-2225.

165. Varshney, R.K.; Close, T.J.; Singh, N.K.; Hoisington, D.A.; Cook, D.R. Orphan legume crops enter the genomics era. Curr. Opin. Plant Biol. 2009, 12, 202-210. [CrossRef]

166. Thudi, M.; Li, Y.; Jackson, S.A.; May, G.D.; Varshney, R.K. Current state-of-art of sequencing technologies for plant genomics research. Brief Funct. Genomic. 2012, 11, 3-11. [CrossRef]

167. Simon, C.J.; Muehlbauer, F.J. Construction of a chickpea linkage map and its comparision with maps of pea and lentil. J. Hered. 1997, 88, 115-119. [CrossRef]

168. Varshney, R.K.; Hiremath, P.J.; Lekha, P.; Kashiwagi, J.; Balaji, J.; Deokar, A.A.; Vadez, V.; Xiao, Y.; Srinivasan, R.; Gaur, P.M.; et al. A comprehensive resource of drought- and salinity- responsive ESTs for gene discovery and marker development in chickpea (Cicer arietinum L.). BMC Genom. 2009, 10, 523. [CrossRef]

169. Crozet, P.; Marghalha, L.; Confraria, A.; Rodrigues, A.; Martinho, C.; Elias, C.A.; Gonzalez, E.B. Mechanism of regulation of SNF1/AMPK1/SnRK1 protein kinases. Front. Plant Sci. 2014, 5. [CrossRef]

170. Maruyama, K.; Sakuma, Y.; Kasuga, M.; Ito, Y.; Seki, M.; Goda, H.; Shimada, Y.; Yoshida, S.; Shinozaki, K.; Yamaguchi-Shinozaki, K. Identification of cold-inducible downstream genes of the Arabidopsis DREB1A/CBF3 transcriptional factor using two microarray systems. Plant J. 2004, 38, 982-993. [CrossRef]

171. Ahanger, M.A.; Akram, N.A.; Ashraf, M.; Alyemeni, M.N.; Wijaya, L.; Ahmad, P. Plant responses to environmental stresses from gene to biotechnology. AoB Plants 2017, 9, 1-17. [CrossRef]

172. Gahlaut, V.; Jaiswal, V.; Kumar, A.; Gupta, P.K. Transcription factors involved in drought tolerance and their possible role in developing drought tolerant cultivars with emphasis on wheat (Triticumaestivum L.). Theor. Appl. Genet. 2016, 129, $2019-2042$. [CrossRef]

173. Li, D.; Zhang, Y.; Hu, X.; Shen, X.; Ma, L.; Su, Z.; Wang, T.; Dong, J. Transcriptional profiling of Medicagotruncatula under salt stress identified a novel CBF transcription factor MtCBF4 that plays an important role in abiotic stress responses. BMC Plant Biol. 2011, 11, 109. [CrossRef]

174. Ferguson, M.E.; Burrow, M.; Schultze, S.R.; Bramel, P.J.; Paterson, A.; Kresovich, S.; Mitchell, S. Microsatellite identification and characterization in peanut (Arachishypogaea L.). Theor. Appl. Genet. 2004, 108, 1064-1070. [CrossRef]

175. Brauner, S.; Murphy, R.L.; Walling, J.G.; Przyborowski, J.; Weeden, N.F. STS markers for comparative mapping in legumes. J. Am. Soc. Hortic. Sci. 2002, 127, 616-622. [CrossRef]

176. Devasirvatham, V.; Tan, D. Impact of High Temperature and Drought Stresses on Chickpea Production. Agronomy 2018, 8, 145. [CrossRef]

177. Singh, D.; Singh, C.K.; Taunk, J.; Tomar, R.S.S.; Chaturvedi, A.K.; Gaikwad, K.; Pal, M. Transcriptome analysis of lentil (Lens culinaris Medikus) in response to seedling drought stress. BMC Genom. 2017, 18, 206. [CrossRef] [PubMed]

178. Nadeem, M.; Li, J.; Yahya, M.; Sher, A.; Ma, C.; Wang, X.; Qiu, L. Research progress and perspective on drought stress in legumes: A review. Int. J. Mol. Sci. 2019, 20, 2541. [CrossRef]

179. Zhang, G.H.; Su, Q.; An, L.J.; Wu, S. Characterization and expression of a vacuolar Na+/H+ antiporter gene from the monocot halophyte Aeluropuslittoralis. Plant Physiol. Biochem. 2008, 46, 117-126. [CrossRef]

180. Singh, D.; Laxmi, A. Transcriptional regulation of drought response: A tortuous network of transcriptional factors. Front. Plant Sci. 2015, 6, 895. [CrossRef]

181. Kudo, M.; Kidokoro, S.; Yoshida, T.; Mizoi, J.; Todaka, D.; Fernie, A.R. Double overexpression of DREB and PIF transcription factors improves drought stress tolerance and cell elongation in transgenic plants. Plant Biotechnol. J. 2017, 15, 458-471. [CrossRef]

182. Yan, K.; Chen, P.; Shao, H.; Shao, C.; Zhao, S.; Brestic, M. Dissection of photosynthetic electron transport process in sweet sorghum under heat stress. PLoS ONE 2013, 8, e62100. [CrossRef] 
183. Sita, K.; Sehgal, A.; Kumar, J.; Kumar, S.; Singh, S.; Siddique, K.H.; Nayyar, H. Identification of high-temperature tolerant lentil (Lens culinaris Medik.) genotypes through leaf and pollen traits. Front. Plant Sci. 2017, 8, 744. [CrossRef]

184. Gosal, S.S.; Wani, S.H.; Kang, M.S. Biotechnology and drought tolerance. J. Crop Improv. 2009, 23, 19-54. [CrossRef]

185. Browne, J.; Tunnacliffe, A.; Burnell, A. Plant desiccation gene found in a nematode. Nature 2002, 416, 38. [CrossRef]

186. Kishor, P.K.; Hong, Z.; Miao, G.H.; Hu, C.A.A.; Verma, D.P.S. Over expression of [delta]-pyrroline-5-carboxylate synthetase increases proline production and confers osmo-tolerance in transgenic plants. Plant Physiol. 1995, 108, 1387-1394. [CrossRef]

187. Anbazhagan, K.; Bhatnagar-Mathur, P.; Vadez, V.; Dumbala, S.R.; Kishor, P.K.; Sharma, K.K. DREB1A over expression in transgenic chickpea alters key traits influencing plant water budget across water regimes. Plant Cell Rep. 2015, 34, 199-210. [CrossRef]

188. Abdelrahman, M.; Al-Sadi, A.M.; Pour-Aboughadareh, A.; Burritt, D.J.; Tran, L.S.P. Genome editing using CRISPR/Cas9-targeted mutagenesis: An opportunity for yield improvements of crop plants grown under environmental stresses. Plant Physiol. Biochem. 2018, 131, 31-36. [CrossRef]

189. Cai, Y.; Chen, L.; Liu, X.; Sun, S.; Wu, C.; Jiang, B.; Hou, W. CRISPR/Cas9-mediated genome editing in soybean hairy roots. PLoS ONE 2015, 10, e0136064. [CrossRef]

190. De Ronde, J.A.; Cress, W.A.; Kruer, G.H.; Strasser, R.J.; Van Staden, J. Photosynthetic response of transgenic soybean plants, containing an Arabidopsis P5CR gene, during heat and drought stress. J. Plant Physiol. 2004, 161, 1211-1224. [CrossRef]

191. Bhatnagar-Mathur, P.; Vadez, V.; Devi, M.J.; Lavanya, M.; Vani, G.; Sharma, K.K. Genetic engineering of chickpea (Cicer arietinum L.) with the P5CSF129A gene for osmoregulation with implications on drought tolerance. Mol. Breed. 2009, 23, 591-606. [CrossRef]

192. Li, Y.; Zhang, J.; Zhang, J.; Hao, L.; Hua, J.; Duan, L.; Li, Z. Expression of an Arabidopsis molybdenum cofactor sulphurase gene in soybean enhances drought tolerance and increases yield under field conditions. Plant Biotechnol. J. 2013, 11, 747-758. [CrossRef]

193. Iuchi, S.; Kobayashi, M.; Yamaguchi-Shinozaki, K.; Shinozaki, K. A stress-inducible gene for 9-cis-epoxycarotenoid dioxygenase involved in abscisic acid biosynthesis under water stress in drought-tolerant cowpea. Plant Physiol. 2000, 123, 553-562. [CrossRef]

194. Li, D.H.; Li, W.; Li, H.Y.; Guo, J.J.; Chen, F.J. The soybean GmRACK1 gene plays a role in drought tolerance at vegetative stages. Russ. J. Plant Physiol. 2018, 65, 541-552. [CrossRef]

195. Kim, H.J.; Cho, H.S.; Pak, J.H.; Kwon, T.; Lee, J.H.; Kim, D.H.; Lee, D.H.; Kim, C.G.; Chung, Y.S. Confirmation of Drought Tolerance of Ectopically Expressed AtABF3 Gene in Soybean. Mol. Cells 2018, 41, 413-422. [CrossRef]

196. Hiremath, P.J.; Farmer, A.; Cannon, S.B.; Woodward, J.; Kudapa, H.; Tuteja, R.; Krishnamurthy, L. Large-scale transcriptome analysis in chickpea (Cicer arietinum L.), an orphan legume crop of the semi-arid tropics of Asia and Africa. Plant Biotechnol. J. 2011, 9, 922-931. [CrossRef] [PubMed]

197. Deokar, A.A.; Kondawar, V.; Jain, P.K.; Karuppayil, S.M.; Raju, N.L.; Vadez, V.; Srinivasan, R. Comparative analysis of expressed sequence tags (ESTs) between drought-tolerant and-susceptible genotypes of chickpea under terminal drought stress. BMC Plant Biol. 2011, 11, 70. [CrossRef] [PubMed]

198. McKersie, B.D.; Bowley, S.R.; Harjanto, E.; Leprince, O. Water-deficit tolerance and field performance of transgenic alfalfa overexpressing superoxide dismutase. Plant Physiol. 1996, 111, 1177-1181. [CrossRef]

199. Manavalan, L.P.; Guttikonda, S.K.; Phan Tran, L.S.; Nguyen, H.T. Physiological and molecular approaches to improve drought resistance in soybean. Plant Cell Physiol. 2009, 50, 1260-1276. [CrossRef]

200. An, J.; Cheng, C.; Hu, Z.; Chen, H.; Cai, W.; Yu, B. The Panax ginseng PgTIP1 gene confers enhanced salt and drought tolerance to transgenic soybean plants by maintaining homeostasis of water, salt ions and ROS. Environ. Exp. Bot. 2018, 155, 45-55. [CrossRef]

201. Li, Y.; Chen, Q.; Nan, H.; Li, X.; Lu, S.; Zhao, X.; Cao, D. Overexpression of GmFDL19 enhances tolerance to drought and salt stresses in soybean. PLoS ONE 2017, 12, e0179554. [CrossRef]

202. Chen, Y.; Chi, Y.; Meng, Q.; Wang, X.; Yu, D. GmSK1, an SKP1 homologue in soybean, is involved in the tolerance to salt and drought. Plant Physiol. Biochem. 2018, 127, 25-31. [CrossRef]

203. Wang, L.S.; Chen, Q.S.; Xin, D.W.; Qi, Z.M.; Zhang, C.; Li, S.N.; Wu, X.X. Overexpression of GmBIN2, a soybean glycogen synthase kinase 3 gene, enhances tolerance to salt and drought in transgenic Arabidopsis and soybean hairy roots. J. Integr. Agric. 2018, 17, 1959-1971. [CrossRef]

204. Khazaei, H.; Caron, C.T.; Fedoruk, M.; Diapari, M.; Vandenberg, A.; Coyne, C.J.; McGee, R.; Bett, K.E. Genetic diversity of cultivated lentil (Lens culinaris Medik.) and its relation to the world's agro-ecological zones. Front. Plant Sci. 2016, 7, 1093. [CrossRef]

205. Upadhyaya, H.D.; Dwivedi, S.L.; Ambrose, M.; Ellis, N.; Berger, J.; Smykal, P.; Debouck, D.; Duc, G.; Dumet, D.; Flavell, A.; et al. Legume genetic resources: Management, diversity assessment, and utilization in crop improvement. Euphytica 2011, 180, 27-47. [CrossRef]

206. Smykal, P.; Aubert, G.; Burstin, J.; Coyne, C.; Ellis, N.; Flavell, A.; Ford, R.; Hýbl, M.; Macas, J.; Neumann, P.; et al. Pea (Pisum sativum L.) in the Genomic Era. Agronomy 2012, 2, 74-115. [CrossRef] 